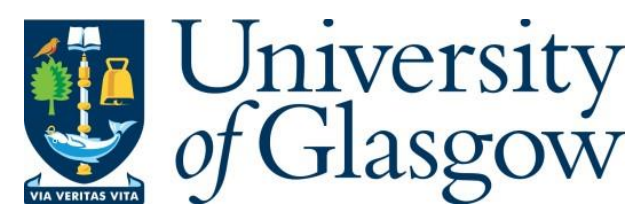

Tams, C. J. (2016) State succession to investment treaties: mapping the issues. ICSID Review: Foreign Investment Law Journal, 31(2), pp. 314-343.

There may be differences between this version and the published version. You are advised to consult the publisher's version if you wish to cite from it.

http://eprints.gla.ac.uk/116860/

Deposited on: 26 February 2016

Enlighten - Research publications by members of the University of Glasgow http://eprints.gla.ac.uk 


\section{STATE SUCCESSION TO INVESTMENT TREATIES: MAPPING THE ISSUES}

\section{Christian J. Tams*}

\section{Introduction}

Over the past two decades, as the discipline has moved into the legal mainstream, investment lawyers have engaged with many core aspects of public international law. Rules on remedies, defences such as necessity, the canons of treaty interpretation, Vienna Convention rules on denunciation - all these now regularly feature in investment jurisprudence and form the subject of engaged commentary. Their increasing relevance reflects the gradual integration of investment law into the international legal discourse. ${ }^{1}$

Among the core aspects of international law, the legal rules governing State succession occupy a special place. State succession - typically understood to mean "the definitive replacement of one State by another in respect of sovereignty over a given territory" ${ }^{2}$ - is one of the lesser-liked branches of public international law. It is widely perceived to be technical, complex and controversial: an area of law characterised by "an almost total doctrinal schism" ${ }^{3}$ (notably between supporters of a continuity approach, and those arguing that new State should be able to start with a 'clean slate' ${ }^{4}$ ), but also by the nitty-gritty detail of bilateral diplomatic practice. Many international lawyers, including those with generalist leanings, tend to steer

\footnotetext{
* The author is Professor of International Law at the University of Glasgow and an Academic Member of Matrix (London) [christian.tams@glasgow.ac.uk].

${ }^{1}$ For academic commentary see e.g. F. Baetens (ed), Investment Law Within International Law: Integrationist Perspectives (2013); R. Hofmann/C.J. Tams (eds), Investment Law and General International Law: From Clinical Isolation to Systemic Integration? (2011); R. Hofmann/C.J. Tams (eds), International Investment Law and Its Others (2012).

2 J Crawford, Brownlie's Principles of Public International Law ( $8^{\text {th }}$ edn., 2012), 423. A very similar definition is set out in Article 2(1)(b) of the 1978 Vienna Convention on Succession of States in Respect of Treaties, United Nations Treaty Series, vol. 1946, 3, and International Legal Materials 17 (1978), 1488.

${ }^{3} \mathrm{M}$ Craven, The Problem of State Succession and the Identity of States under International Law, European Journal of International Law 9 (1998) 142, 143.

${ }^{4}$ See further below, sections 2 and 4 .
} 
clear of it. Until recently, investment lawyers did not show much interest in it either. $^{5}$

In fairness, until recently, State succession to investment treaties may not have seemed a topic worthy of detailed analysis. The contemporary incarnation of the investment protection regime, based on bilateral investment treaties and regular access to international arbitration, is of fairly recent origin after all; it was established simply too late to be affected by the main waves of state succession that swept the international system before the 1970s. To be sure, the most important of them - the decolonisation process that resulted in the creation of dozens of States after 1945 - prompted heated debates about the status of alien property post independence. ${ }^{6}$ However, at the time, these debates typically implicated contractual arrangements and rules of general international law (notably on expropriation) rather than investment treaties and treaty-based arbitration. ${ }^{7}$ In fact, even the next wave of succession, viz. the break-up of States in Central and Eastern Europe during the 1990s, for a while was not considered to raise real issues of investment treaty law. ${ }^{8}$

Yet change seems under way. Two prominent decisions in the pending proceedings between Sanum and the Lao People's Democratic Republic ('Laos') have exposed sharp divisions in the application of State succession rules: in the course of the

\footnotetext{
${ }^{5}$ In a recent piece, Patrick Dumberry lamented "[t]he absence of any research on the issue of State succession to BITs" and criticised tribunals for having, with few exceptions, failed to offer "reasoning on ... basic State succession issues" (which he considered "disappointing"): see An Uncharted Question of State Succession: Are New States Automatically Bound by the BITs Concluded by Predecessor States Before Independence?, Journal of International Dispute Settlement 6 (2015), 74, at 96 .

${ }^{6}$ Mohammed Bedjaoui's Second Report to the UN International Law Commission (discussing economic and financial acquired rights) gives a flavour of the debates: see Second Report on Succession of States in Respect of Matters Other Than Treaties, ILC Yearbook 1969, vol. II, 69.

${ }^{7}$ Newcombe and Paradell make the point very clearly: "The foreign investment disputes that ensued [following decolonization] focused on two principal issues: the extent to which acquired rights, including natural resource concessions granted by colonial powers, were to be respected; and the standard of compensation for the expropriation of those acquired rights" (in Law and Practice of Investment Treaties: Standards of Treatment (2009), at 19).

${ }^{8}$ See below, section 4 , for brief comment.
} 
proceedings, an UNCITRAL tribunal ${ }^{9}$ and the Singapore High Court ${ }^{10}$ disagreed on whether the China-Laos BIT concluded in 1993 applied to Macao (a territory formerly administered by Portugal, but returned to China in 1999). ${ }^{11}$ Arbitration websites report a that "[i]n a dramatic holding" of January 2016, an UNCITRAL tribunal held Kazakhstan to be bound by the terms of a BIT concluded by the Soviet Union, and speculate about further cases turning on issues of state succession. ${ }^{12}$ The existence of independence movements in States fully integrated into the present investment protection regime (in Scotland/the United Kingdom, Catalonia/Spain, etc.) suggests that the issue will remain on the agenda for the foreseeable future. Perhaps unsurprisingly, recent academic commentary has begun to explore the relationship between investment treaties and State succession; however, so far, much of it remains focused on the issues raised in the Sanum litigation ${ }^{13}$ and the perennial "doctrinal schism" ${ }^{14}$ between adherents of 'clean slate' and 'strict continuity' approaches. $^{15}$

\footnotetext{
${ }^{9}$ Sanum Investments Limited $v$ Laos, UNCITRAL (PCA Case No 2013-13), Award on Jurisdiction, 13 December 2013. A related claim has been registered by the parent company Sanum Investment Limited: see Lao Holdings NV v Lao Peoples Democratic Republic (ICSID Case No ARB(AF)/12/6).

${ }^{10}$ Lao People's Republic v. Sanum Investments Limited, Judgment, [2015] SGHC 15.

${ }^{11}$ For brief comment see below, section 5. Kugelmann provides a concise historical account: D Kugelmann, Macau, in Max Planck Encyclopedia of Public International Law (www.mpepil.com).

${ }^{12}$ See LE Petersen, In a dramatic holding, UNCITRAL tribunal finds that Kazakhstan is bound by terms of former USSR BIT with Canada, Investment Arbitration Reporter, 28 Jan 2016 (at

http://www.iareporter.com/articles/in-a-dramatic-holding-uncitral-tribunal-finds-that-kazakhstan-isbound-by-terms-of-former-ussr-bit-with-canada/) and further MD Goldhaber, Arbitration Scorecard 2013: Treaty Disputes, The American Lawyer, at http://www.americanlawyer.com/id=1202607030938/Arbitration-Scorecard-2013-Treaty-Disputes (describing Sudapet Company Ltd. v. Republic of South Sudan - though perhaps not quite accurately, as will become clear in the course of this article - as "the first ICSID dispute [believed] to turn on issues of state succession").

${ }^{13}$ See e.g. N Hart and S Srikumar, Investor-State Arbitration before the High Court of Singapore: Territoriality, Nationality and Arbitrability, Cambridge Journal of International and Comparative Law 4 (2015), 191; G Wang, International Investment Law: A Chinese Perspective (2014), at 568-570; M Hwang and A Chang, Case Comment: Government of the Lao People's Democratic Republic v Sanum Investments Ltd: A Tale of Two Letters, ICSID Review 30 (2015), 506; D Lim, Case Comment: Government of the Lao People's Democratic Republic v Sanum Investments Ltd [2015] SGHC 15, Singapore Law Blog, at http://www.singaporelawblog.sg/blog/article/95; as well as The Virtue of Judicial Restraint: Two Comments on Laos v Sanum, Global Arbitration Reporter, vol. 10/2 (2015), at http://globalarbitrationreview.com/journal/article/33620/virtue-judicial-restraint-two-commentslaos-v-sanum.

${ }^{14}$ Craven (n 3), 143.

${ }^{15}$ See notably Dumberry (n 5 ) as well as id., State Succession to Bilateral Treaties: A Few Observations on the Incoherent and Unjustifiable Solution Adopted for Secession and Dissolution of States under
} 
Against this background of long-term neglect and recent (selective) interest, the present paper presents a bird's eye account of questions of State succession that arise in relation to investment treaties. The approach adopted is deliberately broad: what is intended is not an in-depth discussion of particular problems (such as, for example, the status of Macao under Chinese BITs). Instead, the subsequent considerations are in the form of a conspectus of the legal rules applicable to different types of succession scenarios, offered to inform debate about a particularly tricky area of public international law now confronting investment lawyers.

\section{Succession to Treaties: Basic Features}

When one State replaces another as the sovereign of a particular part of territory, a number of legal problems can arise. Do individuals affected by the change automatically become nationals of the new State? How are State assets and liabilities to be dealt with? What is the fate of claims lodged before the change of sovereignty? And what happens to treaties concluded into prior to that date? These issues all relate to the transfer of some legal entitlement or obligation from one State to another; and they are commonly addressed as questions of 'State succession' ${ }^{16}$ To set the stage for the analysis of problems in relation to investment treaties, a few introductory words about the basic features of legal regime governing State succession seem in order.

the 1978 Vienna Convention, Leiden Journal of International Law 28 (2014), 3 (offering a vigorous critique of the 'strict continuity' approach); and further A Genest, Sudan Bilateral Investment Treaties and South Sudan: Musings on State Succession to Bilateral Treaties in the Wake of Yugoslavia's Breakup, Transnational Dispute Management, vol. 11/3 (2014); Q Qerimi and S Krasniqi, Theories and Practice of State Succession to Bilateral Treaties: The Recent Experience of Kosovo, German Law Journal 14 (2013), 1359. Going beyond country studies, Tai-Heng Cheng provides a fuller analysis, but his approach is based on a rather broad notion of 'State succession', which, contrary to most legal authorities, he understands to encompass "state and government succession": see his State Succession and Commercial Obligations (2006), at 4; and cf. below, section 2.b., for comment.

${ }^{16}$ As Crawford notes, "the phrase 'state succession' is employed to describe an area, a source of problems: it does not connote any overriding principle, or even a presumption, that a transmission or succession of legal rights and duties occurs in a given case"; in this sense, the "municipal analogy of continuity of legal personality in an individual's general property, passing as an inheritance, involving a partial or 'universal succession'" is indeed "misleading": see Crawford (n 2), 423-424; and further M Craven, The Decolonization of International Law: State Succession and the Law of Treaties (2007), at 29-31. 


\section{a) A Fragmented and Disputed Area of Law}

The legal regime governing questions of succession is fragmented and, as a general matter, not well established. ${ }^{17}$ To begin with, its organising concept - the notion of a State's 'replacement in relation to territory' ${ }^{18}$ - is rather diffuse. It covers instances as diverse as the separation (secession) of parts of a State from that State; a dependent territory's move to independence; the complete dismemberment (dissolution) of a State; the incorporation of one State into an existing one; the merger (fusion) of two or more States into a new State; and cessions of territory between existing States. As will be shown in the following, the legal regime of State succession draws distinctions between these different modalities of succession though where and how the lines precisely are drawn is often a matter of debate.

The present inquiry centres on legal relations based on treaties, and it discusses to what extent the successor State succeeds to treaty rights and obligations contracted by its predecessor in the field of investment law. Of the various succession issues enumerated above (succession to debts, to assets, to nationality, etc.) this is perhaps the most protracted. For decades, at least where instances of succession have led to the emergence of a new State, commentators have disagreed on the correct starting-point: should new States be required to adhere to treaty commitments

\footnotetext{
${ }^{17}$ According to the German Federal Constitutional Court, it "one of among the most disputed and least secure parts of international law" ("eine[r] der umstrittensten und unsichersten Teile des gesamten Völkerrechts"): see Collection of Decisions of the Federal Constitutional Court, vol. 96, 68, at 79. For excellent overviews of the legal regime see Crawford (n 2), 423-444; G Hafner and G Novak, State Succession in Respect of Treaties, in DB Hollis (ed), The Oxford Guide to Treaties (2012) 396; A Zimmermann, State Succession in Treaties, in Max Planck Encyclopedia of Public International Law (www.mpepil.com) ('Zimmermann, EPIL'); and A Zimmermann and JG Devaney, Succession to Treaties and the Inherent Limits of International Law, in CJ Tams/ A Tzanakopoulos/A Zimmermann (eds), Research Handbook on the Law of Treaties (2014), 521. Comprehensive accounts are provided by A Zimmermann, Staatennachfolge in völkerrechtliche Verträge- zugleich ein Beitrag zu den Möglichkeiten und Grenzen völkerrechtlicher Kodifikation (2000) ('Zimmermann, Staatennachfolge'); B Stern, La succession d'Etats, in Receuil des Cours, vol. 262 (1996), 9; A Gruber, Le droit international de la succession d'États (1986); PK Menon, The Succession of States in Respect to Treaties, State Property, Archives, and Debts (1991); and DP O'Connell, State Succession In Municipal and International Law, 2 vols. (1967). Based on work conducted since 1994, the International Law Association ('ILA') in 2008 adopted Resolution on 'Aspects of the Law of State Succession'; the resolution and the Committee's Report are available at http://www.ilahq.org/en/committees/index.cfm/cid/11 and contained in ILA, Report of the Seventy Third Conference, Rio de Janeiro (2008).

${ }^{18} \mathrm{Cf}$. Article 2(1)(b) of the 1978 Vienna Convention.
} 
entered into by their predecessors, or should they be able to start 'life' with a clean slate ${ }^{19} 20^{\text {th }}$ century international practice, prompted e.g. by the great waves of territorial re-ordering at the end of the two World Wars and the decolonisation movement, has not provided a clear-cut answer to this question. ${ }^{20}$ From the late 1960s onwards, the UN International Law Commission ('ILC') engaged in a conscious effort of (partial ${ }^{21}$ ) legal clarification and development, ${ }^{22}$ which eventually led to the adoption of the 1978 Vienna Convention on Succession of States in respect of Treaties ('the 1978 Vienna Convention'). ${ }^{23}$ That Convention lays down default rules and provides an important point of reference; but its ratification record is disappointing, ${ }^{24}$ and a number of its normative propositions remain controversial. ${ }^{25}$ As a consequence, the Convention's impact on concrete instances of succession has been mixed: in the more recent cases - the dissolution of the Soviet Union, the CSFR; the break-up of Yugoslavia and the ensuing separation of Montenegro and Kosovo; the emergence of East Timor, Eritrea and South Sudan as new States; and

${ }^{19}$ Craven (n 16) offers a detailed historical account (at 29-92); Zimmermann and Devaney (n 17) present a succinct analysis (at 516-518).

${ }^{20}$ Having surveyed practice, the International Law Commission observed in 1974 that "[a] close examination of State practice afforded no convincing evidence of any general doctrine by reference to which the various problems of succession in respect of treaties could find their appropriate solution": see ILC Yearbook 1972, vol. II/1, 226 (para. 31).

${ }^{21}$ As Brigitte Stern notes, the 1978 Vienna Convention does not aim to regulate succession to treaties comprehensively ( $\mathrm{n} 17$, at 125). Notably, it provides very little guidance on the question of succession to constitutive treaties establishing international organisations: on this see Article 4 of the 1978 Vienna Convention; and further below, section 3 .

${ }^{22}$ The problem of state succession had already been included in Hersch Lauterpacht's 'Survey of International Law in Relation to the Work of Codification of the International Law Commission', UN Doc. A/CN.4/1/Rev.1 (1949). Encouraged by the UN General Assembly's Resolution 1686 (1961), the ILC began to consider question of succession to treaties in the 1960s, with Sir Humphrey Waldock and Sir Francis Vallat acting as special rapporteurs, and in 1974 presented a set of 'Draft Articles and Commentaries on Succession of States in respect of Treaties' (ILC Yearbook 1974, vol. II/1, at 174 et seq.). For details and documents see the ILC's Analytical Guide, at http://legal.un.org/ilc/guide/3_2.shtml\#top.

\footnotetext{
${ }^{23}$ See the reference in $\mathrm{fn} .2$. In parallel, the ILC also worked on other aspects of the law of State succession; this led to the adoption of the 1983 Vienna Convention on Succession of States in respect of State Property, Archives and Debts, International Legal Materials 22 (1983), 306 (not yet in force).

${ }^{24}$ Nearly forty years after its adoption, the Convention has no more than 22 parties: see https://treaties.un.org/pages/ViewDetails.aspx?src=TREATY\&mtdsg_no=XXIII2\&chapter=23\&lang=en.

${ }^{25}$ In its written submissions in the Gabcikovo Nagymaros case before the International Court of Justice, Hungary argued that the 1978 Vienna Convention was "widely regarded as an unsuccessful exercise in international law-making ... which does not correspond to subsequent practice": see Reply of Hungary, 20 June 1995 (http://www.icj-cij.org/docket/files/92/10965.pdf), at 173. For further discussion of one of the Convention's most controversial propositions see below, section 4a.
} 
the territorial transfers of Macao, Hong Kong and Walvis Bay, to name the most prominent - States and other stakeholders have drawn inspiration from it; but perhaps not much more: pragmatism, rather than adherence to abstract legal propositions, has been the guiding principle. ${ }^{26}$ The result is a legal regime characterised, more than in other areas of international law, by a practice of "diplomatic bricolage, the collecting of bits and pieces from normative materials ... lying around in treaties, doctrinal writings and diplomatic discourse" ${ }^{27}$

\section{b) Distinguishing State Succession from Other Phenomena}

Before assessing the work of the 'diplomatic bricoleurs' in the field of investment law, it is useful to delimit the scope of application of the regime of State succession. While the preceding section has emphasised the breadth of the notion of 'State replacement' (which is at the heart of the State succession regime), it is important to note that that regime does not apply to other ruptures affecting treaty relations. Three such other ruptures merit at least some brief comment.

Changes not affecting a State's legal personality: First, State succession needs to be distinguished from changes that do not affect the legal personality of the State. ${ }^{28}$ In essence, where a State, notwithstanding changes to its structure or territory, remains identical, the question of succession to treaties does not arise: as the legal personality of the State remains the same, so do its treaty rights and obligations. ${ }^{29}$

\footnotetext{
${ }^{26}$ As noted by Zimmermann, "recent instances of international practice [in the field of State succession] ... have not followed any hard and fast legal rules": A Zimmermann, The International Court of Justice and State Succession to Treaties: Avoiding Principled Answers to Questions of Principle, in CJ Tams/J Sloan (eds), The Development of International Law by the International Court of Justice (2013), 53, at 54.

${ }^{27} \mathrm{M}$ Koskenniemi, Report of the Director of Studies of the English-Speaking Section of the Centre, in PM Eisemann and M Koskenniemi (eds), State Succession: Codification Tested against the Facts (2000), 65, at 132.

${ }^{28}$ As Craven ( $\mathrm{n} 3$ ) notes, the problem is of "classification or taxonomy", and "structural" in nature (at 146). For succinct accounts see Crawford (n 2), 426-427; Zimmermann/Devaney (n 17), 512-516; for a fuller treatment see Stern (n 17), at 39-86; W Czaplinski, La continuité, l'identité et la succession d'Etats, Revue belge de droit international 26 (1993), 375, and K Marek, Identity and Continuity of States in Public International Law (1968).

${ }^{29}$ As Zimmermann notes, "[a]s a matter of principle, State continuity and State succession are mutually exclusive concepts": A Zimmermann, Continuity of States, in Max Planck Encyclopedia of Public International Law (www.mpepil.com), at para. 6.
} 
All this is clear in theory, but can be highly problematic in practice, as there are relatively few agreed criteria for determining when a State changes its personality: to illustrate, was the Federal Republic of Yugoslavia, comprising the territory of the former Yugoslav Republics of Serbia and Montenegro, identical to the Socialist Federal Republic of Yugoslavia (SFRY), comprised of Serbia, Montenegro, Croatia, Slovenia, Macedonia and Bosnia Herzegovina? Could Russia claim after 1991 claim to be identical to the Soviet Union? Objective factors, such as the impact of the change on a State's structure, may be indicative; ${ }^{30}$ but much depends on the subjective perception of the change, by the State itself and by the international community ${ }^{31}$ which eventually decided to reject the FRY's claim to continuity, but accepted Russia's. ${ }^{32}$ As is clear from these two examples, the proper legal assessment often is the result of a lengthy process of claim and contestation, in which historical narratives, perceptions of legitimacy and the views of key players play an important role. Yet while indeed "precarious", ${ }^{33}$ the distinction between identity and succession remains fundamental as a matter of law.

Regime change: Second, instances of State succession need to be distinguished from changes to the State's internal system of government. Premised on a change in the State's legal personality, the law of State succession ignores ruptures in the domestic organisation of the State. ${ }^{34}$ This does not mean that such ruptures had no impact on

\footnotetext{
${ }^{30}$ Stern provides a thorough analysis of international practice: see $\mathrm{n} 17$, at 68-82.

${ }^{31}$ Zimmermann and Devaney (n 17), at 515: "what often matters most is not objective facts, such as the size of territory or population, but rather to what extent the claim to continuation of identity was generally accepted by the inter- national community as a whole, including international organizations".

${ }^{32}$ For contemporary perspectives see $\mathrm{R}$ Mullerson, The Continuity and Succession of States by Reference to the Former USSR and Yugoslavia, International ad Comparative Law Quarterly 42 (1993), 473; M Shaw, State Succession Revisited, Finnish Yearbook of International Law 5 (1994), 34. It is worth noting that in the case concerning Application of the International Convention on the Elimination of All Forms of Racial Discrimination (Georgia v Russia), the International Court of Justice referred to the Respondent as "the State continuing the legal personality of the Union of Soviet Socialist Republics": ICJ Reports 2008, 353, para. 105.

${ }^{33}$ Crawford (n 2), 427.

${ }^{34}$ Historically, claims to discontinuity advanced by new, often socialist, regimes (such as the Soviet Union in 1917, or Cuba after the Cuban revolution) have met with opposition. (Hafner and Nowak refer to this as the "socialist aberration" of the clean slate theory: $n$ 17, at 401). Introducing its Draft Articles on the Succession of States in Respect to Treaties, the ILC stated that it had "concluded that it was appropriate to exclude from the scope of the draft articles problems of succession arising as a
} 
the State's external relations: the more drastic changes in fact are likely to have consequences for the State's approach to international treaties. However, these changes will result from re-negotiations of existing treaties or the new regime's decision to suspend or terminate existing treaties (which may be valid or not), or to agree to new ones. They do not result from the operation of rules governing State succession.

Illegal occupation of territory: Finally, the regime of State succession to treaties does not apply to situations of illegal occupation of territory. These involve ruptures of a particular kind, to which international law responds with particular sets of rules, notably aimed at precluding the validation, in law, of the situation created in fact. ${ }^{35}$ As a general principle, conduct of the occupying State is governed by the regime of belligerent occupation, as well as human rights law and international humanitarian law to the extent that these rules apply extraterritorially. The regime of State succession does not come into play. ${ }^{36}$

Yet even when instances of State identity, regime change and illegal occupation are left to a side, the list of 'proper' of State succession issues remains considerable. The subsequent sections group them into three distinct categories, which take up internal divisions within the applicable legal regime: (i) Section 3 analyses the

result of changes of regime brought about by social or other forms of revolution" (ILC Yearbook 1974, vol. II, at 170). See further Marek (n 28), 24 et seq.

${ }^{35}$ Hence annexations procured by force are illegal, and must not be recognised as lawful by third States: see General Assembly Resolution 2625 (XXV) ('Friendly Relations Declaration'), principle I ("No territorial acquisition resulting from the threat or use of force shall be recognized as legal"); General Assembly Resolution 3314 (XXX) ('Definition of Aggression'), at Article 5(3) ("No territorial acquisition or special advantage resulting from aggression is or shall be recognized as lawful"); and Articles 40, 41 of the ILC's Articles on State Responsibility. For details see R Hofmann, Annexation, in Max Planck Encyclopedia of Public International Law (www.mpepil.com); and L Mälksoo, Illegal Annexation on State Continuity (2003).

${ }^{36}$ According to its Article 6, the 1978 Vienna Convention "applies only to the effects of a succession of States occurring in conformity with international law"; pursuant to Article 40, ist provisions "shall not prejudge any question that may arise in regard to a treaty from the military occupation of a territory." For a detailed discussion see Marek (n 28), 73 et seq. Examining a recent (on-going) conflict, Thomas Grant states that "there is no indication that Ukraine would accept that a succession of States has taken place in respect of Crimea (or any other territory recognized to fall within the State borders of Ukraine)": see his Aggression Against Ukraine: Territory, Responsibility, and International Law (2015), at 94 . 
position of new States vis-à-vis the ICSID Convention (as the most relevant dispute settlement framework). (ii) Section 4 inquires whether new States are bound by bilateral investment treaties ('BITs') concluded by their predecessors. (iii) Section 5 looks at the particular problems of territorial cessions and their impact on investment treaties. Finally, section 6 offers a number of general conclusions and highlights open questions.

\section{New States and ICSID Membership}

As a threshold issue, questions of succession arise with respect to membership in the ICSID Convention regime. Can a successor State simply automatically follow the predecessor State's ICSID membership and exercise membership rights? Conversely, can investors lodge claims against successor States if their predecessor had been an ICSID party? Or do successor States only become bound by the ICSID Convention once they have joined the regime as a new treaty party, in line with the procedures set out in Articles 67 and 68? The proceedings in the case of MNSS B.V. et. al. v. Montenegro, a BIT-based arbitration brought against Montenegro in 2011, ${ }^{37}$ illustrates that these questions are not of a purely academic character: Montenegro had not, at the time of the request for arbitration, ratified the ICSID Convention in its own right; but the Socialist Federal Republic of Yugoslavia (from which Serbia and Montenegro emerged) had. ${ }^{38}$ So was Montenegro, in 2011, to be treated as a 'Contracting State' for the purposes of Article 25 of the ICSID Convention? ${ }^{39}$ The subsequent sections address this, and related, questions by outlining the general regime governing succession to membership (a) and applying it to the special case of ICSID (b).

\footnotetext{
${ }^{37}$ Information provided on the ICSID website is limited; but see 'Montenegro to Face Second Known Investment Treaty Claim, This Time Over Bankrupt Steelworks', Investment Arbitration Reporter, 10 December 2012, at http://www.iareporter.com/articles/montenegro-to-face-second-knowninvestment-treaty-claim-this-time-over-bankrupt-steelworks/.

${ }^{38}$ Montenegro signed the ICSID Convention on 19 July 2012 and ratified it on 10 April 2013. In line with Article 68 of the Convention, it therefore became bound on 10 May 2013. Details on Montenegro's membership, and that of other contracting parties, are listed in Doc. ICSID/3 ('List of Member States'), at https://icsid.worldbank.org/apps/ICSIDWEB/about/Pages/Database-of-MemberStates.bak.aspx.

${ }^{39}$ As Schreuer, Malintoppi, Reinisch and Sinclair note, "[p]articipation in the Convention of the State party to proceedings is an absolute requirement": see The ICSID Convention. A Commentary ( $2^{\text {nd }}$ edn., 2011), at 144
} 


\section{a) The General Regime: Between Orthodox Principle and Pragmatic Application}

On the face of it, membership in the ICSID Convention could be looked at as regular question of succession to treaties. However, it concerns a treaty of a particular kind, namely one establishing an international organization, viz. the International Centre for the Settlement of Investment Disputes ('Centre'). While the Centre is closely affiliated with the World Bank and while its activities, compared to that of other international organisations, are not the most visible, it possesses an autonomous legal personality ${ }^{40}$ and enjoys privileges and immunities commonly granted to international organisations. ${ }^{41}$ As for the 'inner life' of the Centre, once they have joined the Convention, contracting parties participate in the Centre's deliberations and decisions, notably through the Administrative Council; ${ }^{42}$ they are members of an international organization as much as parties to a multilateral treaty.

All this has implications for the applicable rules on State succession. ${ }^{43}$ Because of the higher level of integration within international organizations, the orthodox approach has long treated membership as a special category of treaty participation: a

\footnotetext{
${ }^{40}$ See Article 18 of the ICSID Convention. The Report of the Executive Directors leaves no doubt in this respect; it states: "The Convention establishes the International Centre for Settlement of Investment Disputes as an autonomous international institution (Articles 18-24)" (in ICSID Reports, vol. 1, at 26).

${ }^{41}$ Such as: immunity from suit, tax exemptions and the like: see Articles 19-24 of the ICSID Convention.

${ }^{42}$ See notably Articles 4, 6, 10 and 17 of the ICSID Convention (regulating the composition and functions of the Administrative Council); and further Article 7 (procedure) and Article 13 (designation of panelists).

${ }^{43}$ For details on succession to membership see $\mathrm{K}$ Bühler, State Succession and Membership in International Organizations: Legal Theories Versus Political Pragmatism (2001); id., State Succession, Identity/Continuity and Membership in The United Nations, in Koskenniemi/Eisemann (n 27), 187; HG Schermer and NM Blokker, International Institutional Law (4th ed., 2003), 81-91; and, more briefly, Crawford (n 2), 442-443.

From the beginning of its work on questions of succession, the ILC had separated questions of membership in international organisations from the other aspects of succession to treaties: see Report by Manfred Lachs, ILC Yearbook 1963, vol. II, 260, at 261 (para. 13). Article 4(a) of the 1978 Vienna Convention recognises the special character of membership rights: it clarifies that, as regards the acquisition of membership in international organisations (which could be seen a question of succession to the constitutive treaty), the 1978 Vienna Convention is "without prejudice to the rules concerning acquisition of membership and without prejudice to any other relevant rules of the organization".
} 
"personal status" ${ }^{44}$ not easily transferred unless explicitly envisaged in the organization's constituent documents. ${ }^{45}$ Pursuant to this "traditional axiom of nonsuccession to membership", ${ }^{46}$ new States have regularly been expected to go through the organisation's admissions process and join as new members. ${ }^{47}$

The orthodox approach has however not been followed through rigorously; "political pragmatism" has (to adapt the subtitle of a detailed study) to some extent mollified the strictures of "legal theories" or "traditional axioms". ${ }^{48}$ Pragmatic considerations have e.g. led international organisations to accept a claim to continued membership, where a new State had been established through a fusion of previous members (as in the case of Yemen, which came into existence in 1990 when North and South Yemen merged), or where a State could credibly claim to revert to a prior membership status (e.g. Syria and Egypt after the dissolution of their short-lived merger into the United Arab Republic). ${ }^{49}$ The practice of certain financial institutions (including the World Bank) seems equally to have been driven by pragmatism rather than strict application of principle: desirous to preserve assets deposited by predecessor States, the IMF and the World Bank, during the 1990s, e.g. treated the Czech and Slovak Republics, as well as the various States emerging during the break-

\footnotetext{
${ }^{44}$ Crawford (n 2), 443; K Zemanek, State Succession after Decolonization, Recueil des Cours 161 (1965), 182, at 253 ("[m]embership of international organizations is a personal right to which, in principle, succession is not possible"); CW Jenks, State Succession in Respect of Law-Making Treaties, British Yearbook of International Law 29 (1952), 105, at 134. In its Report (n 17) the ILA speaks of a "coloration fortement personnelle" (at 43).

${ }^{45}$ Only in rare instances do constitutive documents expressly permit the acquisition of membership by way of succession, usually for newly independent States that had possessed some form of prior status within the organisation: see e.g. the 1953 International Sugar Agreement (Article 66), and the 1960 (Second) International Tin Agreement (Article XXII(6). A right to succeed to the 1899 and 1907 Hague Dispute Settlement Conventions was created by a unanimous decision of the PCA Administrative Council in 1959. For details and references see Bühler (n 43), 26-30.

${ }^{46}$ Bühler (n 43), 30.

${ }^{47}$ This approach was followed within organisations with a formal process of admission, as well as those that permitted admission by virtue of a unilateral act: see Bühler ( $n$ 43), 31-32; Schermers/Blokker (n 43), 90.

${ }^{48} \mathrm{Cf}$. the subtitle of Bühler's detailed study (n 43).

${ }^{49}$ See Schermers/Blokker ( $\mathrm{XX}$ ), 82: "In these cases [Yemen, United Arab Republic, etc], the new state replaced the old ones as a member of the international organizations in which they had participated. No new admission was required, not even where one of the constituent parts of the federation had not previously been a member of the organization" (footnote omitted). Bühler provides details ( $\mathrm{n} 43$, at 50 et seq.).
} 
up of Yugoslavia, as successors of the CSFR and the SFRY. ${ }^{50}$ Drawing on this more recent practice, commentators have put forward distinctions based on the character of the organization concerned - excluding succession to membership within political organisations emphasising close integration, while admitting it in principle for 'universal-technical organisations' aimed at wide participation. ${ }^{51}$ Yet while that distinction may serve as a useful guideline flexibility is the defining feature of legal regime: largely unconstrained by firm rules, international organisations are free to determine issues of membership in light of their institutional preferences. ${ }^{52}$

\section{b) ICSID Practice: Orthodoxy Affirmed}

Against this background, ICSID's institutional practice merits attention. It is, as has been noted, "scant" ${ }^{13}$ (as in many instances, the respective predecessor States had not been ICSID parties, and hence succession was not an option ${ }^{54}$ ). But contrary to views expressed by commentators, ${ }^{55}$ the scant practice yields relatively straightforward results. Although ICSID aspires to universal membership and allows World Bank members to join without undergoing any admissions procedure, ${ }^{56}$ it has

\footnotetext{
${ }^{50}$ This was widely considered to be a break with the orthodox approach: see e.g. PR Williams, State Succession and the International Financial Institutions: Political Criteria v. Protection of Outstanding Financial Obligations, International and Comparative Law Quarterly 43 (1994), 776, 807: "As a result of the break-up of Yugoslavia and Czechoslovakia, the IMF and World Bank have for the first time developed a conditional succession approach to address the questions posed by the break-up of a member State." According to Oeter, "State practice in this field seems to differ considerably from state practice concerning membership in other organizations - a fact largely due to different voting procedures and different states of interest dominating in these organizations": in ILA Report (n 17), at 43.

${ }^{51}$ See e.g. Bühler in Koskenniemi/Eisemann (n 43), at 227-233.

${ }^{52}$ As noted by the ILA in its 2008 Report, this limits the purchase of general rules: "Tout conflit entre les règles de la succession d'Etat et toute règle relative à l'acquisition de la qualité de membre ou toute autre règle pertinente de l'organisation - disposition qui inclut les règles issues de la pratique des organisations - se résout en faveur de ces dernières. C'est l'intérêt de l'organisation et son équilibre institutionnel qui sont protégés et qui doivent l'emporter sur l'intérêt individuel de l'Etat successeur" (n 17, at 46)

${ }^{53}$ Schreuer et al. (n 39), at 169 (footnote 401).

${ }^{54}$ This e.g. applies to the Soviet Union and Ethiopia (in relation to Eritrea). Insofar as colonial powers, pursuant to Article 70, applied the ICSID Convention to overseas territories for whose representation they bore responsibility (e.g. the Netherlands in respect of Suriname and the Netherlands Antilles), no attempt has been made to 'upgrade' the status of these territories to full membership.

${ }^{55}$ Contrast e.g. JA Fratermann Secession, State Succession and International Arbitration, available at http://papers.ssrn.com/sol3/papers.cfm?abstract_id=2313401 (at 19).

${ }^{56}$ Article 67 runs as follows: "This Convention shall be open for signature on behalf of States members of the Bank. It shall also be open for signature on behalf of any other State which is a party to the
} 
clearly followed the orthodox approach precluding succession to membership. Invariably, new States that have joined the ICSID Convention have done so as new members, even though this opened up a time-gap in the application of the ICSID regime. ${ }^{57}$ This practice has been followed in relation to the following new States: ${ }^{58}$

- the Czech and Slovak Republics (which joined as new parties in 1993/1994 rather than continuing the CSFR's prior membership),

- the agreed successor States of the SFRY (itself a first-generation ICSID member since 1967), namely Slovenia (admitted as a new member in 1994), Bosnia and Herzegovina (1997), Croatia (1998) and the Former Yugoslav Republic of Macedonia (1998);

- Serbia, which joined as a new member in 2006 after the separation of Montenegro and after it had given up its earlier claim to continue the legal personality of the SFRY; subsequently by

- Montenegro, which (as noted above) joined in 2013, after its separation from Serbia and Montenegro; as well as Kosovo and South Sudan, which unsurprisingly did not seek to continue the membership status of Serbia or Sudan, but instead joined as new parties in 2009 and 2012, respectively.

The brief summary of practice reflects the continued appeal of the 'traditional axiom $^{59}$ : even though membership rights and duties are relatively limited, ICSID membership is regarded as a personal link with the organization that a new State needs to establish in its own right. Succession has neither been sought nor granted; in fact, new States often have joined ICSID quickly so to signal their integration into the international economic community or - particularly in cases of contested statehood, such as Kosovo's - their status as a member of the community of nations.

Statute of the International Court of Justice and which the Administrative Council, by a vote of twothirds of its members, shall have invited to sign the Convention." Schreuer et al. (n 39) note that initial drafts envisaged a more open regime that would have opened the Convention for signature by all sovereign States; this however, was resisted by representatives of divided States (at 1267-1268).

${ }^{57}$ According to Article 68(2), the Convention enters into force for them 30 days after the deposit of their instrument of ratification, accession or approval. Until that date, the new State therefore is not a "Contracting State" for the purposes of Article 25 of the Convention.

${ }^{58}$ The following information is based on information provided by ICSID: see Doc. ICSID/3 (which contains further details on membership).

${ }^{59}$ Bühler (n 43), 30. 
ICSID's handling of the MNSS B.V. et. al. v. Montenegro case confirms this approach, and illustrates its implications. Having requested arbitration under the ICSID Convention, the claimants realised that Montenegro was not a 'Contracting State' in the sense of Article 25 of the ICSID Convention and, irrespective of whether it had consented to arbitration in an applicable BIT, could not be a respondent in ICSID proceedings. According to the Investment Arbitration Reporter's account, "[t]he claimants therefore requested ICSID's approval to make use of the Additional Facility Rules, which was granted on 7 December 2011. After delays of nearly a year, a formal notice of arbitration was lodged in November of 2012, and it is understood that ICSID ultimately registered the dispute under the Additional Facility Rules on 6 December 2012." ${ }^{\prime 60}$

\section{New States and Bilateral Investment Treaties}

As is clear from the preceding section, a new State's decision not to join the ICSID regime need not be fatal, as investors can explore other jurisdictional options (Additional Facility proceedings, UNCITRAL proceedings, etc.). Such proceedings, however, presuppose that the new State has consented to some form of investment arbitration. The subsequent considerations focus on the most relevant basis of consent, namely bilateral investment treaties; they ask whether new States are bound by investment agreements concluded by their predecessor. This question has arisen, and continues to arise, quite frequently, as all new States that have emerged since the 1990s have had to take a position on the fate of prior BITs. To illustrate, based on publicly available information, ${ }^{61}$ at the time of its demise the Czech and Slovak Federal Republic ('CSFR') was party to 16 BITs; 38 BITs were in force for Serbia and Montenegro when Montenegro separated from it in $2006{ }^{62}$ while Sudan, upon

\footnotetext{
60 See http://www.iareporter.com/articles/montenegro-to-face-second-known-investment-treatyclaim-this-time-over-bankrupt-steelworks/ (December 2012).

${ }^{61}$ See the information on applicable BITs (and dates of their entry into force) provided at http://investmentpolicyhub.unctad.org/IIA/liasByCountry\#iialnnerMenu.

${ }^{62}$ Serbia and Montenegro was established on 27 April 1992, as the 'Federal Republic of Yugoslavia' ('FRY'), proclaimed on the territory of two of the constituent parts of the territory of Yugoslavia, i.e.
} 
the independence of South Sudan, had entered into at least ${ }^{63} 13$ BITs. With respect to all of these - and the many more BITs at stake during the break-up of the former Yugoslavia and the Soviet Union, etc. - it needs to be assessed whether the respective successor States, after independence, are bound by treaties concluded by their predecessors. ${ }^{64}$

The question of succession to treaties has long been, and remains, highly controversial. It is here that the major debate between 'strict continuity' and 'clean slate' approaches has historically been played out. The 1978 Vienna Convention's attempt to provide a strong default rule favouring continuity has met with limited success. Rather than endorsing one guiding principle, practice and debates since 1978 reflect a trend towards process (encouraging negotiated agreements on treaty succession) and flexibility (proposing differentiated solutions for different categories of treaties). The subsequent sections outline these developments (a) and indicate how they affect the status of new States with respect to bilateral investment treaties entered into by their predecessors (b).

\section{a) The General Regime: Automatic Succession, Its Discontents, and the Turn to}

\section{Process and Flexibility}

The general regime is not easily summarised, as it is rather in a state of flux and a number of core propositions remain uncertain. This, in turn, is a result of an overambitious attempt at codification based on overarching principle, and a body of practice favouring case-by-case solutions. The 1978 Vienna Convention stands for the first approach. It set out a relatively straightforward rule: according to its Article

Serbia and Montenegro. In 2003, the name of FRY was amended to 'State Union of Serbia and Montenegro'. In 2006, Monetenegro separated from that Union to form an independent State. For reasons of simplicity, the text uses 'Serbia and Montenegro' to describe the State existing between 1992-2006.

${ }^{63}$ According to UNCTAD's recent country study, the figure is significantly higher: see Investment Policy Review: Sudan (http://unctad.org/en/PublicationsLibrary/diaepcb2014d5_en.pdf, at 54), which lists 21 BITs.

${ }^{64}$ It is worth noting in passing that, irrespective of debates about the level of customary protection, in investment law, it is protection by treaty that matters, as only the treaty will typically confer upon claimants a right to raise treaty violations before arbitral tribunals, and as that right will be restricted to treaty breaches. As a consequence, one of the common arguments in succession debates - that customary international law would offer continuous protection - provides no easy way out. 
34, new States - whether seceding from existing States or emerging in processes of dismemberment - are bound by all treaties binding upon their predecessors. ${ }^{65}$ There are, to be sure, nuances. Importantly, the rule of automatic succession applies by default. States can always agree otherwise (Article 34(2)(a)); and new States do not automatically succeed if "the application of the [prior] treaty in respect of the successor State would be incompatible with the object and purpose of the treaty or would radically change the conditions for its operation" (Article 34(2)(b)). ${ }^{66}$ What is more, the Convention adopts a very different approach for newly independent States that have obtained independence from colonial rule: these remain bound by localized, territorially-grounded treaties, ${ }^{67}$ but otherwise can start with a 'clean slate'. $^{68}$

Yet notwithstanding these nuances, the Convention's approach is surprisingly straightforward. Outside the colonial context, and outside the relatively narrow exception of Article 34(2)(b), new States are presumed to continue all treaty rights and obligations of their predecessors, irrespective of whether these derive from multilateral or bilateral agreements. This no doubt has the appeal of simplicity, but in retrospect, it seems clear that, for a treaty seeking to attract wide participation, the 1978 Vienna Convention may have adopted too straightforward an approach. Ever since draft provisions foreshadowing Article 34 appeared during the 1970s, the

\footnotetext{
${ }^{65}$ The crucial provision is Article 34(1)(a), which provides: "When a part or parts of the territory of a State separate to form one or more States, whether or not the predecessor State continues to exist: (a) any treaty in force at the date of the succession of States in respect of the entire territory of the predecessor State continues in force in respect of each successor State so formed...". According to Zimmermann, the question addressed by Article 34 "may be considered the most controversial question within the law of state succession to treaties": Zimmermann, in Tams/Sloan (n 26), 59.

${ }^{66}$ Article 34(2)(b).

${ }^{67}$ Articles 11 and 12; and see Crawford (n 2), 439-440. The ICJ affirmed the customary status of Article 12 in the Gabcikovo Nagymaros case: see ICJ Reports 1997, 7, at para. 123.

${ }^{68}$ See Article 16, which runs as follows: "A newly independent State is not bound to maintain in force, or to become a party to, any treaty by reason only of the fact that at the date of the succession of States the treaty was in force in respect of the territory to which the succession of States relates." According to Article 24, bilateral treaties are "considered as being in force between a newly independent State and the other State party when: (a) they expressly so agree; or (b) by reason of their conduct they are to be considered as having so agreed". For comment see Hafner/Novak (n 17), 409-410; and Zimmermann/Devaney (n 17), at 518 (arguing that, during the decolonization process, "the universal succession to obligations of previous colonial powers was seen as completely irreconcilable .... [this] ultimately resulted in the inclusion of the special regime for newly independent States in the VCSST").
} 
automaticity principle has been widely criticised as overly broad (failing to reflect the diverse practice of States) and as unjust (based, as it is, on a categorical distinction between newly-independent and other successor States). ${ }^{69}$ Resistance to automatic succession in fact is said to be a relevant factor explaining the low acceptance rate of the 1978 Vienna Convention as a treaty. ${ }^{70}$

Given these concerns, it comes as no surprise that Article 34 has had a limited impact on international practice. In fact, there is widespread agreement that international practice since 1978 does not bear out a general rule of automatic succession for all treaties. ${ }^{71}$ Rather than relying on the operation of one overarching principle, States have sought actively to shape the fate of 'their' treaty rights and obligations post independence. The various State successions of the 1990s in particular resulted in rich body of treaty practice, including unilateral declarations by successor States, agreements with their treaty partners, and depositary statements, which provide guidance on the fate of specific treaties. ${ }^{72}$ This practice has usually accommodated a general desire to avoid ruptures; as a consequence, in the majority of instances, the States involved in negotiations have sought to ensure the stability of treaty relations. ${ }^{73}$ But this overarching goal has been reached in different ways, and pursued with different degrees of vigour.

\footnotetext{
${ }^{69}$ See e.g. Crawford (n 2), 438-439; Hafner/Novak (n 17), 413-414; A Aust, Modern Treaty Law and Practice (2rd edn., 2007), 368-369; D Vagts, State Succession: The Codifiers' View, Virginia Journal of International Law 33 (1993), 275, at 283; Dumberry (n XX), 78 ("both incoherent and unjustifiable"). O'Connell's criticism of the Convention was particualrly trenchant; to him, "this particular essay in refashioning the law was marred from its inception by a preoccupation with the special problem of decolonisation, around which myth and emotion have accumulated like mists in the marsh, so that the whole context became intellectually distorted": see DP O'Connell, Reflections on the State Succession Convention, Zeitschrift für ausländisches öffentliches Recht du Völkerrecht 39 (1979), 725, at 726 .

${ }^{70}$ Vagts (n 69), 287-288.

${ }^{71}$ See e.g. Crawford (n 2), 438; J Klabbers, Cat on a Hot Tin Roof: The World Court, State Succession, and the Gabcikovo-Nagvmaros Case, Leiden Journal of International Law 11 (1998), 345, at 348-349.

${ }^{72}$ In its Report, the ILA made the point very clearly, when noting that negotiations are the most common means of addressing succcession issues (n 17, at 27): "la pratique de la négociation prévaut concernant la succession en matière de traités".

${ }^{73}$ According to the ILA, negotiations proceed from a 'presumption of treaty continuity': see ILA Report (n 17, at 27): "la présomption de la continuité est la prémisse fondamentale en matière de succession d'Etats - afin de sauvegarder la stabilité des relations internationales".
} 
A case-by-case handling of succession issues, which has been aptly described as a turn from 'substance' (or substantive legal principle) to 'procedure' (or process), ${ }^{74}$ can no doubt clarify the status of particular treaties. However, it has left the general regime in a state of flux: outside party agreement on the continuity (or discontinuity) of a given treaty, there is a rather large grey zone of uncertainty. At the same time, the more recent debate reflects a desire for greater differentiation and flexibility: while terms such as 'strict continuity' and 'clean slate' remain popular, practice has sought to explore "more nuanced solutions". ${ }^{75}$ For present purposes, two such "nuanced solutions" - both of which point to a more flexible handling of succession issues - are of particular relevance.

A first approach proceeds from a distinction between different categories of treaties. While a general rule of automatic succession for all treaties (as envisaged by Article 34 of the 1978 Vienna Convention) seems overly ambitious, practice might support a more restrictive rule requiring new States to succeed to major multilateral conventions formulating 'gold standards' of international relations, in which there is a clear community interest in automatic succession. ${ }^{76}$ For universal human rights agreements in particular, it has been argued that, as "[t]he rights enshrined in [human rights agreements] belong to the people ..., once the people are accorded the protection of the rights ..., such protection devolves with territory and continues to belong to them, notwithstanding ... State succession". ${ }^{77}$ By contrast, this first approach has tended to view bilateral treaties as mere inter-party bargains, dominated by the personal element and of an "essentially voluntary character". ${ }^{78}$

\footnotetext{
${ }^{74}$ Koskenniemi (n 27), 69.

${ }^{75}$ Zimmermann, EPIL (n 17), para. 5. See also Zimmermann/Devaney (n 17, at 516): "false dichotomy".

${ }^{76}$ The different views on this matter are reflected in MT Kamminga, State Succession in Respect of Human Rights Treaties, European Journal of International Law 7 (1996), 469; A Rasulov, Revisiting State Succession to Humanitarian Treaties: Is There a Case for Automaticity?, European Journal of International Law 14 (2003), 141; Zimmermann/Devaney (n 17), at 533-536; and Aust (n 69), at 371372.

${ }^{77}$ Human Rights Committee, General Comment No. 26 (61), UN Doc. CCPR/C/21/Rev.1/Add.8/Rev.1 (1997), at para. 4. While enjoying considerable support, practice regarding major multilateral conventions is not unequivocal, and the ICJ, in the various Genocide cases submitted to it, has refrained from endorsing a rule of limited automaticity: see Zimmermann, in Tams/Sloan (n 26, at 6163) for a detailed assessment.

${ }^{78}$ As noted by the ILC in its commentary to the Draft Articles on Succession of States in Respect of
} 
According to most commentators, whatever the general rule, bilateral treaties are not subject to a rule of automatic succession; ${ }^{79}$ according to the ILA, "the[ir] fate ... is generally decided through negotiation between the successor State and the other party". ${ }^{80}$

A second approach seeks differentiated solutions on the basis of a fuller appreciation of the parties' intentions. Of course, in an ideal case, those intentions will be expressed in formal agreements or declarations of succession (which, as mentioned above, have become a popular means of clarifying which treaties apply). But even in the absence of such explicit guidance, practice seems to have accepted some degree of flexibility. Notably, domestic courts have on occasion continued to apply prior treaties on the basis of presumed (tacit) consent, where "continuity [was] in every State's interest". ${ }^{81}$ Where this was the case (as e.g. in relation to extradition or FCN treaties), domestic courts have not infrequently relied on informal statements or conduct to establish consent; ${ }^{82}$ and "[s]ometimes simple intertia [has been] upgraded as continuity". ${ }^{83}$ Similarly, in the Croatian Genocide case, the International Court of Justice read a fairly general policy statement adopted by an un-authorised assembly of parliamentarians as amounting to a valid declaration of succession. ${ }^{84}$ Needless to say, such attempts to infer consent from statements or conduct faces "inherent difficulties"; ${ }^{85}$ however, given the uncertainty of the applicable legal

Treaties: ILC Yearbook 1974, vol. II/1, at 239.

${ }^{79}$ Stern (n 17), 315-316; Dumberry (n 5), 78-82; Shaw (n 32), 67; as well as J Klabbers, M Koskenniemi and $O$ Ribbelink and A Zimmermann (eds), State Practice Regarding State Succession and Issues of Recognition (1999), 116.

${ }^{80}$ ILA 2008 Resolution (n 17), para. 8.

${ }^{81}$ Koskenniemi (n 27), 89. According to O’Connell (n 69, at 736), “[t]he clearly personal treaties, such as commercial or extradition treaties, have given rise to no problems".

${ }^{82}$ See e.g. R. Director of Public Prosecution, ex parte Schwartz (Jamaica), 73 ILR, $45-48$ (1987) (continued application of a US-UK extradition treaty); $M$ v. Federal Department of Justice and Police (Switzerland) (continued application of a UK-Swiss treaty in regard to South Africa), 75 ILR, 109-113 (1987); Re Bottali (Italy) (continued application of an extradition treaty between Italy and India), 78 ILR 111 (1988); and further Gruber (n 17), 206-216.

${ }^{83}$ Koskenniemi (n 27), 89.

${ }^{84}$ Namely in the Croatian-Serbian Genocide case, ICJ Reports 2008, 412, at para. 108. For comment see Zimmermann in Tams/Sloan (n 26), at 67-68.

${ }^{85}$ Genest (n 15), 22. 
standards, the attraction of "pragmatic arguments from tacit consent" ${ }^{86}$ is obvious. And overall, it may perhaps be said that the more flexible approaches just outlined facilitate the search for equitable solutions reflecting the intentions of the parties, and at least offer guidelines for the application of a fairly unsettled legal framework.

\section{b) Succession to BITs: Widespread Treaty Practice, and the Need to Look Beyond It} As noted above, there has so far been no comprehensive effort to apply the general rules on State succession to bilateral investment treaties. Arbitral practice has yet to engage fully with the issues; where succession questions have arisen, tribunals have generally preferred to tread softly. Commentators have only recently begun to explore arguments about succession to BITs; and while there is now a body of commentary, ${ }^{87}$ it remains focused on the grand normative debate - do new States automatically succeed to prior BITs? This question no doubt is relevant; but in light of the preceding considerations, it need not always arise. In fact, the trends towards process and flexibility highlighted above mean that quite often, it can be avoided. To illustrate this point, and seeking to present a balanced account of potential issues arising in investment treaty disputes, the subsequent sections provide an (admittedly selective) overview of recent treaty practice regarding succession to BITs (aa), and highlight factors that, in the absence of express agreement, could indicate that the parties implicitly agreed to the continued application of a prior BIT (bb). Following these considerations, section (cc) briefly revisits the debate about automatic succession to BITs.

\section{aa) Explicit Party Agreements}

The first point is based on a rather trite proposition: before rehearsing arguments about automatic succession to treaties, it is useful to analyse whether "the fate of [a BIT has been] decided through negotiation between the successor State and the other party..." ${ }^{88}$. This in fact happens rather frequently: successor States and their treaty partners regularly provide explicit answers to questions of State succession.

\footnotetext{
${ }^{86}$ Cf. Koskenniemi (n 27), 89.

${ }^{87}$ See e.g. Dumberry (n 5), id. (n 15); Genest (n 15).

${ }^{88}$ Cf. ILA Resolution (n 17), para. 8.
} 
The full extent of this practice is difficult to assess, if only because information is not always readily available. ${ }^{89}$ Yet an illustrative review of two of the better-documented instances of State succession suggests that practice is significant.

Serbia and Montenegro: The practice of Serbia and Montenegro (which was widely considered a successor to the Socialist Federal Republic of Yugoslavia ['SFRY' or 'former Yugoslavia'], and which eventually gave up its claim to have continued the former Yugoslavia's legal personality ${ }^{90}$ ) provides a first example in point. By late 1991, the SFRY had entered into seven BITs. ${ }^{91}$ With respect to three of these seven prior treaties, Serbia and Montenegro and its respective treaty partner agreed that the old treaty would continue to apply: this is true with respect to France, the Netherlands and Germany. ${ }^{92}$ In two further instances, Serbia and Montenegro, during the 2000s, entered into a new BIT with the treaty partners of the former SFRY: this applies to Egypt and Austria. ${ }^{93}$ (Serbia and Montenegro also concluded a new BIT with the Netherlands, with which it had initially agreed to continue the old SFRY BIT. ${ }^{94}$ ) Importantly, according to their express terms, the new BITs entered

\footnotetext{
${ }^{89}$ The decision in favour of continuity is typically embodied in a bilateral agreement, which in turn is often part of a wider decision about the future of treaty relations between the parties. Yet not all such agreements are made public; comprehensive findings would depend on a detailed examination of diplomatic practice. Such a detailed examination is beyond the scope of the present inquiry, which draws on information made available via government websites, dedicated investment law databases, and published collections of treaty practice.

${ }^{90}$ See supra, section 2.b.

${ }^{91}$ Namely with Canada (1973), the Netherlands (1976)), France (1974), Egypt (1977), Sweden (1978), Germany (1989), Austria (1989). The five latter treaties are available at http://investmentpolicyhub.unctad.org; the Canadian and Dutch treaties are at http://www.treatyaccord.gc.ca/text-texte.aspx?id=101508 (https://verdragenbank.overheid.nl/en/Verdrag/Details/011240 respectively.

92 See bilateral agreeements recorded in http://www.diplomatie.gouv.fr/traites/affichetraite.do?accord=TRA20030037 (France), https://zoek.officielebekendmakingen.nl/trb-2002-181.HTML (Netherlands), and Federal Gazette (Bundesgesetzblatt) 1997, vol. II, 961 (Germany).

Following its independence in 2006, Montenegro agreed with Germany and France that the old SFRY BIT would continue to apply: see Federal Gazette (Bundesgesetzblatt) 2011, vol. II, 746 (Germany); http://www.diplomatie.gouv.fr/traites/affichetraite.do?accord=TRA00000468 (France). Following Kosovo's declaration of independence, the parties agreed that the old SFRY BITs would apply to Kosovo: see http://www.diplomatie.gouv.fr/traites/affichetraite.do?accord=TRA00000940 (France) and Federal Gazette (Bundesgesetzblatt) 2011, vol. II, 748 (Germany).

${ }^{93}$ See Austria-Serbia/Montenegro BIT (2001); Egypt-Serbia/Montenegro BIT (2005).

${ }^{94}$ See Netherlands-Serbia/Montenegro BIT (2002).
} 
between Serbia and Montenegro on the one hand, and Egypt, Austria and the Netherlands on the other, terminated (and thus replaced) the prior SFRY agreements. ${ }^{95}$ While such a termination provision may have been included to clarify the situation, its existence suggests that the new treaty parties did not consider to have started from a clean slate.

In short, of the seven BITs entered into by the SFRY, five were either expressly continued or replaced by new BITs. In the two remaining cases, the situation is more equivocal. Based on readily available information in the public domain, Sweden and Serbia and Montenegro seem not to have reached an explicit agreement to continue the old SFRY-Sweden BIT (nor concluded a new BIT); yet the old BIT was clearly treated as applicable in proceedings between the European Commission and Sweden before the European Court of Justice. ${ }^{96}$ Canada did enter into a new BIT with Serbia in 2014 (i.e. after the separation of Montenegro), but this treaty remains silent on the fate of the SFRY-Canada BIT. ${ }^{97}$ As is clear from these latter two examples, the practice of treaty parties post succession does not address all the issues. However, an analysis of Serbian-Montenegrin practice suggests that diplomatic exchanges between the States concerned significantly reduce the areas of uncertainty.

Czech Republic: The treatment of BITs entered into by Czech and Slovak Federal Republic ('CSFR' or 'former Czechoslovakia') yields even clearer findings. At the time of its dissolution, 16 BITs were in force for the CSFR. During the dissolution of the CSFR, the Czech Republic (as well as the Slovak Republic) indicated that it would consider itself bound by multilateral and bilateral treaties entered into by the

\footnotetext{
${ }^{95}$ See Austria-Serbia/Montenegro BIT (2001), Article 12(4); Egypt-Serbia/Montenegro BIT (2005), Article 13; Netherlands-Serbia/Montenegro BIT (2002), Article 14(5). The 'replacement clauses' of these treaties are not identical, but relatively similar. By way of illustration, Article 12(4) of the Austria-Serbia/Montenegro BIT (2001) provides that "[t]he entry into force of this Agreement between the Government of the Republic of Austria and the Federal Government of the Federal Republic of Yugoslavia shall terminate the provisions of the Agreement on the Promotion and Protection of Investments between the Republic of Austria and the Socialist Federative Republic of Yugoslavia, signed in Belgrade on 25 October 1989."

${ }^{96}$ See European Court of Justice, Commission of the European Communities v. Kingdom of Sweden, Case C-249/06.

${ }^{97}$ See http://investmentpolicyhub.unctad.org/Download/TreatyFile/3152,
} 
CSFR. ${ }^{98}$ Following independence, the Czech Republic and its treaty partners clarified the future application of bilateral treaties concluded with the CSFR. In 14 of the 16 cases, the Czech Republic and its respective treaty partner explicitly agreed that the prior CSFR BIT would continue to apply, typically by including the prior treaty on a list of treaties that would "remain in force": agreements along the lines were reached with the Netherlands, ${ }^{99}$ Austria, ${ }^{100}$ Switzerland, ${ }^{101}$ Germany, ${ }^{102}$ France, ${ }^{103}$ the United Kingdom, ${ }^{104}$ the United States, ${ }^{105}$ as well as Denmark, Finland, Spain, Sweden, Greece, Norway, the United States and the Belgium-Luxembourg Economic Union. ${ }^{106}$ In the two remaining instances (the CSFR-China and CSFR-Canada BITs), new BITs were concluded. Both of these new BITs expressly terminated (and thus replaced) the treaties agreed with the $\mathrm{CSFR}^{107}$ - again suggesting that the old BITS had not simply ceased to apply. In fact, the Czech-Canadian BIT accepted that the prior CSFR-Canada would "continue to apply to any dispute between either Contracting Party and an investor of the other Contracting Party that has been

\footnotetext{
${ }^{98}$ See e.g. 'Proclamation to all Parliaments and Nations of the World' of 17 December 1992, reproduced in Klabbers et. al. (n 79), at 402; see also Article 5(2) of Constitutional Act No. 4/1993 (at http://www.usoud.cz/fileadmin/user_upload/ustavni_soud_www/Pravni_uprava/AJ/4_1993_EN.pdf) . It is worth noting the former Czechoslovakia had been a party to the 1978 Vienna Convention.

${ }^{99}$ See Tractatenblad 1995, Nr. 27, at 3, 5: see https://zoek.officielebekendmakingen.nl/trb-199527.HTML

100
} See http://www.bmwfw.gv.at/Aussenwirtschaft/investitionspolitik/Documents/Bilaterale\%20Investitions schutzabkommen/Tschechien2.pdf.

${ }^{101}$ See www.admin.ch/opc/de/classified-compilation/19900247/index.html\#fn1.

${ }^{102}$ Federal Gazette (Bundesgesetzblatt) 1993, vol. II, 762.

${ }^{103}$ See http://www.diplomatie.gouv.fr/traites/affichetraite.do?accord=TRA19950270.

${ }^{104}$ See UK Treaty Series 1996, Third Supplementary List, 96.

${ }^{105}$ According to Williams, on 24 April 1993, the Czech Ministry of Foreign Affairs notified the US Department of State of a number of prior bilateral agreements (incl. the CSFR-US BIT) that it considered to remain in force: PR Williams, The Treaty Obligations of the Successor States of the Former Soviet Union, Yugoslavia, and Czechoslovakia: Do They Continue in Force?, Denver Journal of International Law and Policy 23 (1994-1995), 1, at 40-41. According to information provided by the US Trade Representative "[a]fter the breakup of Czechoslovakia in 1993, [the CSFR-US BIT] continued in effect for the successor states, the Czech Republic and Slovakia" (at http://tcc.export.gov/Trade_Agreements/All_Trade_Agreements/exp_002809.asp). See also Dumberry (n 5), 85 (his fn. 72).

${ }^{106}$ See the references in Klabbers et. al. (n 79), at 442, 444, 454, 458, 460.

${ }^{107}$ Czech-Chinese BIT, Article 13(4); Czech-Canadian BIT, Article XV(7). 
submitted to arbitration pursuant to that Agreement by the investor prior to the date that this Agreement enters into force." ${ }^{108}$

The brief summary suggests that, when addressing the fate of prior BITs, the Czech Republic and its treaty partners opted for a near-absolute continuity. Against that background, it should perhaps not come as a huge surprise that arbitral tribunals addressing the rather many BIT-based claims against the Czech Republic have seen little reason to provide detailed reasoning. As Dumberry notes, most of the relevant awards "barely mentioned ... the relevant succession issues"; ${ }^{109}$ indeed often ${ }^{110}$ they no more than record, in a single phrase, that "the Czech Republic succeeded to the rights and obligations of the Czech and Slovak Federal Republic under the Treaty". ${ }^{111}$ And while brief statements like this one may indeed not do full justice to the intricacies of the law of State succession, the tribunals' telegraphic "reasoning" no doubt gives effect to the intention of the treaty parties. In the various proceedings against the Czech Republic, it simply (as noted by another tribunal) was "not in dispute that the Respondent succeeded to the rights and obligations under the BIT as originally entered into by the Czech and Slovak Federal Republic". ${ }^{112}$

\footnotetext{
${ }^{108}$ Czech-Canadian BIT, Article XV(7). The provision also refers to "the Agreement between the Government of Canada and the Government of the Czech and Slovak Federal Republic for the Promotion and Protection of Investments, done at Prague on 15 November 1990, insofar as it is now an Agreement between Canada and the Czech Republic" (emphasis added).

${ }^{109}$ Dumberry (n 5), 96. See ibid., 84-89, for a fuller review of arbitral jurisprudence in cases involving the Czech and Slovak Republics.

${ }^{110}$ Similarly brief is the 'discussion' in the following awards: Binder v. Czech Republic, UNCITRAL, Final Award, 15 June 2007, para. 385; European Media Ventures SA v. The Czech Republic, UNCITRAL, Partial Award on Liability, 8 July 2009, para. 1; Invesmart v. Czech Republic, UNCITRAL, Award, 26 June 2009, para. 8; Eastern Sugar BV (Netherlands) v The Czech Republic (SCC Case No 088/2004), Partial Award, 27 March 2007, para. 5.

${ }^{111}$ See CME Czech Republic BV v Czech Republic, UNCITRAL, Partial Award, 13 September 2001, at para. 3.

112 ECE Projektmanagement \& Kommanditgesellschaft PANTA Achtundsechzigste Grundstücksgesellschaft mbH \& Co. v. The Czech Republic, UNCITRAL, PCA Case No. 2010-5, Award, 19 September 2013, para. 3.139.
} 
This summary review of Czech and Serbian-Montenegrin practice illustrates the importance of explicit party agreements determining the fate of prior treaties. Such agreements may be difficult to trace and often are reached some time after the succession, leaving the law uncertain during the interim ('twilight') period. However, the two case studies suggest that explicit agreements are numerous and, in a large number of instances, clarify whether a new State is bound by treaties entered into by its predecessor. As to the outcome of such agreements, Czech and SerbianMontenegrin practice is also indicative: when discussing the fate of a prior treaty, the Czech Republic, Serbia and Montenegro and their respective treaty partners have almost inevitably opted for some form of continuity - typically by agreeing that an old BIT should continue to apply, alternatively by replacing it with a new one. This practice reflects the considerable appeal of stability in investment treaty relations and it bears out Cheng's more general observation that "[i]n most instances of succession, accepting the overall continuity of commercial arrangements is the only realistic option." 113

\section{bb) Inferring Consent}

While treaty parties are numerous, they do not cover all BITs, and of course they may take time to be reached. Even States that are keen to clarify the state of their treaty rights and obligations post independence may need time to reach agreement with their treaty partners. In other instances, new States, for a number of reasons, may struggle to identify the manifold bilateral treaties raising issues of State succession. To illustrate, the position of South Sudan vis-à-vis prior BITs remains largely uncertain. At the time of writing and based on the publicly available information, of the (at least ${ }^{114}$ ) 13 BITs entered into by Sudan, only one has been the subject of an explicit agreement, and even in respect of that one treaty, information is incomplete. ${ }^{115}$ As regards the fate of the twelve other treaties that applied

\footnotetext{
${ }^{113}$ Cheng (n 15), 404.

${ }^{114}$ See supra, information in fn. 63.

${ }^{115}$ The German government website states that the Germany-Sudan BIT applies in relation to South Sudan: http://www.bmwi.de/DE/Themen/Aussenwirtschaft/Investitionsschutz/investitionsschutzvertraege.h tml. It does not refer to a formal agreement to this effect, though.
} 
between Sudan and its respective treaty partners, publicly available information provides no clear guidance.

The question is how to deal with this uncertainty. According to one approach, "diplomatic clarifications or express statements ... represent the only way to lift the cloud of uncertainty"116 - which seems to suggest that all other instances would be covered by the general rule governing succession to bilateral treaties. Such an approach is straightforward, but too categorical; it ignores the trend towards flexibility that characterises the general regime of State succession. ${ }^{117}$ As noted above, the crucial question is whether the new State and the other party to the prior treaty intended to apply the treaty post independence. Especially in the bilateral context, where the parties' intention to be bound by a treaty does not need to be expressed in a formal manner, ${ }^{118}$ there is certainly room for a broader analysis that looks beyond explicit party agreements. ${ }^{119}$ Whilst definitive findings will depend on an overall assessment of the available evidence, the following elements could guide the analysis:

- Unilateral statements by the successor State: In the absence of an explicit bilateral agreement between the treaty parties, successor States may have unilaterally taken a view on the application of prior bilateral treaties. Such unilateral statements cannot bind putative treaty partners, ${ }^{120}$ but they may help identify the view of one party. Where the view of that party is not opposed, it can provide the basis for an

\footnotetext{
${ }^{116}$ Discussing putative obligations of South Sudan post independence, Genest e.g. notes that "diplomatic clarifications or express statements ... represent the only way to lift the cloud of uncertainty hovering over the Sudan BITs in respect of South Sudan" (n 15, at 22).

${ }^{117}$ See supra, section 4.a.

${ }^{118}$ Contrast e.g. the more formalised process governing expressions to be bound by multilateral treaties; these often prescribe specific modes of becoming bound (accession, ratification, etc.) and typically designate a depositary to ensure questions of consent, party status, are handled impartially.

${ }^{119}$ See Aust (n 69), 369: "In the case of a bilateral treaty, much depends on what can be agreed, expressly or tacitly, between the successor state and the third state" (italics in the original). More generally, see also J Brunnée, Consent, in Max Planck Encyclopedia of Public International Law (www.mpepil.com), at para. 20: "Individual States' explicit consent remains central, in both the initial adoption and subsequent development of treaties. In the latter context, attenuated forms of consent, such as consent that is presumed subject to opt-out, are increasingly common."

${ }^{120}$ See Article 9 of the 1978 Vienna Convention, which clarifies that, in and of themselves, unilateral statements cannot create rights and obligations for third States.
} 
argument based on tacit party consent. By way of illustration, it is indicative that in a number of disputes against the Czech and Slovak Republic, investment tribunals relied on unilateral statements as evidence of the new States' willingness to continue prior treaty obligations. ${ }^{121}$ In the recent UNCITRAL award in World Wide Minerals v. Kazakhstan (which, as noted above, has not been released so far), the Claimants are equally said to have "adduced a series of specific statements and representations by Kazakhstan that were alleged to signal that country's intent to be bound by this particular U.S.S.R. BIT" ${ }^{122}$

- Unilateral statements by the putative treaty partner: Conversely, statements by the putative treaty partner may provide guidance. By way of illustration, treaty partners of the predecessor State may have formulated expectations about the successor State's approach to prior treaties, e.g. before extending recognition. ${ }^{123}$ While such expectations may not easily be enforceable post recognition, they can provide the basis of a tacit agreement if the successor State accepts them.

- Statements contained in devolution or related agreements: Devolution agreements between the States involved in a negotiated process of separation or dissolution, just as further arrangements, provide another "rich source of data on the law on succession". ${ }^{124}$ Like unilateral statements by the successor State, they do not as such

\footnotetext{
${ }^{121}$ See e.g. Saluka Investments BV v Czech Republic (UNCITRAL), Jurisdiction over the Counterclaim, 7 May 2004: "The Czech Republic confirmed to the Kingdom of The Netherlands that, upon the separation of the Czech and Slovak Federal Republic into two separate republics, the Treaty remained in force between the Czech Republic and the Kingdom of The Netherlands" (at para. 2). The key question is whether the other party can be taken to have consented: this depends on the regular operation of principles governing consent inferred from silence or passivity; the specificity and authority of the unilateral statement are relevant in this respect.

122 Investment Arbitration Reporter, In Dramatic Holding... (n 12).

${ }^{123}$ For example, Williams refers to letters sent by US President Bush to the Prime Ministers of the Czech and Slovak Republics on 1 December, proposing "that the United States and the respective states 'conduct full diplomatic relations' based on the affirmation of the Republics to fulfill a number of commitments, including the 'commitment to fulfill the treaty and other obligations of the former Czechoslovakia'“. While Williams criticises "the deficiency of the U.S. approach to securing continuation of bilateral bilateral treaties", arbitral practice has accepted the continued application of the prior treaties. See PR Williams (n 105), at 30 and 32; and cf. supra, section 4.b.aa. for a summary of arbitral practice.

${ }^{124}$ Cheng (n 15), 262.
} 
bind third parties; ${ }^{125}$ but they can help identify a new State's approach to prior treaty obligations. In 1991, the members of the newly-established Commonwelath of Independent States ('CIS') e.g., in a general manner, affirmed their desire to "discharge the international obligations incumbent on them under treaties and agreements entered into by the former Union of Soviet Socialist Republics". ${ }^{126}$ As regards South Sudan, a bilateral cooperation agreement of 2012 recorded the intention of Sudan and South Sudan to abide by obligations arising out of their membership in global and regional trade organisations and "other similar institutions". ${ }^{127}$ As the other types of evidence mentioned, none of this need be conclusive: broad statements such as those made by the CIS member States may too general to provide evidence of a willingness to continue specific treaties; ${ }^{128}$ while the more specific Sudan-South Sudan Agreement may not cover obligations under BITs. ${ }^{129}$ However, there is little reason to ignore the agreements altogether.

- Conduct during proceedings: In addition to earlier statements, the successor State's conduct during arbitral proceedings may be relevant. While the applicability of a BIT is a matter for objective determination by the tribunal, the respondent State's views in the proceedings may be indicative. ${ }^{130}$ In some of the proceedings brought against the Czech and Slovak Republics, arbitral tribunals e.g. seemed willing to treat questions of succession en passant because the Claimant and Respondent were

\footnotetext{
${ }^{125}$ See Article 8 of the 1978 Vienna Convention.

${ }^{126}$ Minsk Agreement (establishing the Commonweath of Independent States), International Legal Materials 31 (1992), 147, at Article 12; and further the Declaration of Almaty, ibid., at 148.

127 Agreement on Trade and Trade-Related Issues, Article 2 (at http://sudanwatch.blogspot.de/2013/03/full-text-nine-agreements-between-sudan.html).

${ }^{128}$ But see the reference, in $\mathrm{fn} . \mathbf{8 4}$, to the ICJ's judgment in the Croatian-Serbian Genocide case, in which a general declaration was treated as a valid declaration of succession.

${ }^{129}$ See Genest (n 15), at 5: "Articles 2(1) and 2(2) [of the Agreement on Trade and Trade-Related Issues] raise two unanswered questions with likely negative answers: first, whether the Sudan BITs constitute a body of rules arising out of the membership to an institution similar to the WTO, and second whether they constitute 'other relevant trade principles'."

${ }^{130}$ Support for the general proposition (that conduct during the proceedings is relevant) can e.g. be found in the case of US v. Bowe, in which the Privy Council found that "the two Governments have shown by their conduct, including their conduct in the present proceedings, that they both intended their extradition arrangements to remain in force" (International Law Reports, vol. 85, 144; emphasis added).
} 
agreed on the matter. ${ }^{131}$

The list is illustrative rather than exhaustive: clearly, in seeking to establish the intention of the parties, tribunals or other decision-makers are not bound to a strict canon of admissible sources. It also bears re-iterating that, whatever evidence has been brought forward, will need to be evaluated in the light of all factual circumstances. However, with these caveats, the preceding considerations suggest that, such intention can be deduced from other statements, or inferred from conduct. In this respect, the absence of an explicit party agreement on (dis)continuity does not conclude matters; it means that the matter needs to be studied more fully.

\section{cc) Automatic Succession to BITs?}

In the light of the preceding considerations, the question of automatic succession may perhaps not arise frequently; in many disputes, the treaty parties, explicitly or implicitly, have expressed a view. Nevertheless, it remains relevant, both conceptually and in relation to cases in which the parties' intention cannot be established.

On the basis of the general regime of State succession (controversial as it is), the argument for automatic succession to bilateral treaties meets with considerable obstacles. Of course, new States would automatically be bound by prior BITs if Article 34 of the 1978 Vienna Convention applied (which it hardly ever does). Yet, as noted above, ${ }^{132}$ the better view is that Article 34 does not reflect customary international law - and that it certainly does not reflect customary international law as far as bilateral treaties are concerned: as long as these are seen as one category, and viewed as inter-party bargains of an "essentially voluntary" character, the case

\footnotetext{
${ }^{131}$ See e.g. HICEE BV v Slovak Republic, UNCITRAL (PCA Case No 2009-11), Partial Award, 23 May 2011, at para. $3 \mathrm{fn}$. 2: "It is not in dispute that, after the dissolution of the Czech and Slovak Federal Republic on 31 December 1992, the Slovak Republic succeeded to the [CSFR-Netherlands BIT]."

${ }^{132}$ See supra, section 4.a.
} 
for automatic succession is weak. ${ }^{133}$ The fact that, when determining the fate of BITs through explicit agreements, new States and their treaty partners have almost inevitably opted for treaty stability, does not necessarily affect this understanding. As in other areas of international law, the impact of explicit treaty agreements on the underlying customary norm is ambivalent: while explicit agreements reflect the appeal of continuity (and thus the ratio of Article 34), the fondness of States for negotiated outcomes can equally be said to undermine the case for automatic succession. ${ }^{134}$ On the basis of these arguments, recent studies reject the view that new States were automatically bound by prior BITs; unless the parties have agreed otherwise, the new State position starts with a clean 'BIT slate'. ${ }^{135}$

There is force to such an approach, but perhaps it does not do full justice to arguments in favour of automatic succession to BITs. If that case were made, ${ }^{136}$ it would need to be based on analysis that looks beyond the number of parties, and that takes issue with the characterisation of BITs as "essentially voluntary" interState arrangements. ${ }^{137}$ An argument for automaticity could instead emphasise that,

\footnotetext{
${ }^{133}$ See ILC Yearbook 1974, vol. II/1, at 239; and cf. supra, section 4.a.

${ }^{134}$ See Dumberry (n 5), 82: "the very fact that such negotiation took place in most cases suggests that third States have generally not accepted the principle of automatic succession."

${ }^{135}$ See Genest (n 15), 9 (arguing that "clean slate and mutual consent should prevail for all seceding states in respect of bilateral treaties"); Dumberry (n 15), 27 ("the tabula rasa principle should apply to all new states"); Dumberry (n 5), 81 ("there is no automatic continuity of bilateral treaties because of the particular nature of these treaties. Any treaty continuation is ultimately the result of the express (or tacit) agreement of both States" [footnotes omitted]).

${ }^{136}$ So far, to the author's knowledge, the case for automaticity has not so far been set out in detail. For a clear exposition of its likely starting point - in the context of a separate State succession question - see the the affidavit of Sir Daniel Bethlehem submitted in the Sanum proceedings before the Singapore High Court: At para. 42, Sir Daniel notes: "While it is a treaty between the PRC and Laos, binding on the two States as parties, [the China-Laos BIT] also establishes a legal framework that is expressly intended for the benefit of private persons who qualify as 'investors', both natural persons and economic entities (PRC/Laos BIT, Article 1(2)). More specifically, Articles 2-6 of the BIT create rights for qualified investors that are actionable in their own name under the dispute settlement provisions of Article 8 of the BIT. So, although the BIT is an instrument concluded by the PRC and Laos, and binding upon them, it also creates actionable rights for natural and legal persons having the nationality, or which are established under the laws, of the Contracting States. As the Article 12(4) legal framework stability clause makes clear, such persons have acquired rights and legitimate expectations in the arrangements established by the BIT": see Sanum Investments Limited v. Lao People's Democratic Republic, Affidavit of Sir Daniel Bethlehem KCMG QC, at http://www.italaw.com/cases/documents/3696. For more on the Sanum case see below, section 5.

${ }^{137}$ In the Sanum case, the arbitral recognised that not all bilateral treaties could be treated alike: "the Tribunal considers that it would be excessive to say that all bilateral treaties are so personal, so related to intuitu personae questions that they cannot survive a State's succession. In other words,
} 
while concluded between States, BITs establish substantive rights of investors, which are directly enforceable in arbitral proceedings. While formally bilateral, it does indeed seem overly restrictive to view BITs merely as inter-State bargains. Yet once the focus is broadened to include the interests of foreign investors, two related arguments in favour of automaticity could be advanced. First, treaty-based investor rights could be likened to 'vested' or 'acquired' rights, which occupied a prominent place in traditional debates about State succession - and which were claimed by many to survive instances of State succession. ${ }^{138}$ Applied to the present context, one could perhaps argue that foreign investors making an investment when a BIT applies should acquire the right to have that investment protected by the BIT after the State succession has taken place. ${ }^{139}$

Second, pressing the point in light of recent arguments about automatic succession to particular categories of treaties, there might be room for a 'human rights analogy': adapting a prominent dictum by the UN Human Rights Committee, one could indeed argue that, as rights under BITs "belong [to foreign investors]..., once [foreign investors] are accorded the protection of the rights under the [treaty], such protection devolves with territory and continues to belong to them, notwithstanding ... State succession". ${ }^{140}$

the Tribunal considers that it is necessary to consider the application of the general rule to bilateral treaties on a case-by-case basis" (n 9, at para. 281).

${ }^{138}$ See notably O'Connell (n 17), vol. 1, 304 et seq. For details see Ko Swan Sik, The Concept of Acquired Rights in International Law: a Survey, in $\mathrm{H}$ Meijers and B Vierdag, Essays on International Law and Relations in Honour of A.J.P. Tammes (1977), 120; and MI Torres Cazorla, Rights of Private Persons on State Succession: an Approach to the Most Recent Cases, in Eisemann/Koskenniemi (n 27), 663.

${ }^{139}$ See e.g. Vagts (n 69), 281: "States in their relations with each other are entitled to rely on each other's commitments. ... In other cases, the individual citizens do the relying - they make investments in the territory of the other state because of the assurance (often contained in a treaty of friendship, commerce and navigation or bilateral investment treaty) that they have a right to establish themselves and that their investment will not be taken from them except upon prompt, adequate and effective compensation." It is worth noting that, in order for such an argument to open the way towards treaty-based arbitration, one would need to argue that rights acquired under an applicable BIT are opposable to the successor State as a matter of treaty law.

${ }^{140}$ Human Rights Committee, General Comment No. 26 (61), UN Doc. CCPR/C/21/Rev.1/Add.8/Rev.1 (1997), at para. 4. 
These points are purposively put tentatively, as the debate is at an early stage - and as quite often, the parties have determined the fate of their BITs explicitly or implicitly. It must be recognised that the case argument for automatic succession to BITs is anything but straightforward. It depends on a particularly investor-friendly reading of those treaties, which - given recent backlashes against investment arbitration - may have lost some of its appeal. However, the brief sketch of potential arguments suggests that the matter is at least open to argument.

Of the various succession issues addressed in the present inquiry, the question of succession to prior BITs is the most relevant. As the preceding discussion suggests, it eschews a clear-cut answer. The general regime governing succession to treaties offers relatively limited guidance; as a consequence, States are well advised to determine the fate of BITs through explicit agreements. Where such agreements are concluded, they clearly bear out the immense appeal of treaty continuity.

Absent explicit agreements, tribunals and other decision-makers are likely, in future disputes, to establish the parties' intentions from 'circumstantial evidence', such as unilateral statements or conduct. This approach now doubt is fraught with "inherent difficulties", ${ }^{141}$ but, if undertaken properly, can facilitate the search for equitable solutions. Finally, future disputes may witness a return to the 'big debate' about automatic succession to treaties, which so far has hardly begun: as noted in the preceding paragraphs, with respect to BITs creating investor rights, that debate is perhaps more open than the literature on succession to bilateral treaties suggests.

\section{Cession, Incorporation and Their Impact on Investment Treaties}

Questions of treaty succession are not restricted to the emergence of new States. The broad definition set out in Article 2(1)(b) of the 1978 Vienna Convention brings

\footnotetext{
${ }^{141}$ Genest (n 15), 22.
} 
within the scope of succession instances in which an existing State "replace[s] ... another in the responsibility for the international relations of territory". Cessions of territory (i.e. the agreed transfer of a piece of territory from one State to another ${ }^{142}$ ) and incorporation (i.e. the voluntary integration of one State into another ${ }^{143}$ ) are cases in point. As they do not involve the emergence of a new State, these instances of succession give rise to particular issues and are subject to a particular regime. At least with respect to cessions, this particular regime is enshrined in Article 15 of the 1978 Vienna Convention, which declares that following the transfer of territory, “(a) treaties of the predecessor State cease to be in force in respect of the territory to which the succession of States relates" while "(b) treaties of the successor State are in force in respect of the territory to which the succession of States relates." This provision is widely held to reflect general international law; ${ }^{144}$ unlike with respect to other questions of State succession, debates therefore proceed from an agreed starting-point.

That said, the recent Sanum litigation has thrown into stark relief the considerable uncertainties in the application of the law. As noted in the Introduction, in early 2015, the Singapore High Court held that the 1993 China-Laos BIT did not apply to an investor incorporated under the laws of Macao; this directly contradicted an earlier finding by an UNCITRAL tribunal. ${ }^{145}$ The subsequent discussion seeks to identify the source of this dispute and situate it within the legal regime governing treaties during instances of cession or incorporation; beyond that, it also shows that, notwithstanding the prominence of the conflicting decisions in the Sanum

\footnotetext{
${ }^{142}$ O Dörr, Cession, in Max Planck Encyclopedia of Public International Law (www.mpepil.com), para. 1; Hafner/Novak (n 17), 404; Zimmermann, Staatennachfolge (n 17), 17.

${ }^{143}$ Dörr (n 142), para. 2; Hafner/Novak (n 17), 405; Zimmermann, Staatennachfolge (n 17), 19.

${ }^{144}$ See e.g. In its commentary to draft article 14 (which became Article 15 of the 1978 Vienna Convention), the ILC made clear that the provision codified an existing customary rule Yearbook ILC 1974, vol. II/1, 208-209. Hafner/Novak note succinctly that "State practice before $1978 \ldots$ has confirmed the validity of this rule [Article 15] as part of customary international law" (n 15, at 411). For further support see Zimmermann, EPIL (n 17), para. 8; K Odendahl, Commentary to Article 29, in 0 Dörr/K Schmalenbach (eds), The Vienna Convention on the Law of Treaties (2012), 500. In the Sanum case, the arbitral tribunal noted that there was "unanimity or 'quasi-unanimity' among the doctrine to consider that Article 15 ... represents customary international law" (n 9, at para. 221).

${ }^{145}$ See references in $\mathrm{fn} .8$ and 9.
} 
proceedings, the rules applicable to this type of State succession are in fact rather settled.

\section{a) The General Regime: Moving Treaty Frontiers}

The general regime has been developed by reference to instances of cession. It is premised on the understanding that, while a part of territory is transferred, the legal personality of the transferring and receiving States remains intact. ${ }^{146}$ In this scenario, the widely accepted default rule leaves the treaty status of the two States untouched and merely extends the geographical scope of treaties by moving their 'frontiers'. The result is relatively straightforward: as noted by Zimmermann, "treaties of the predecessor cease to be in force in respect of the ceded territory while treaties of the successor generally extend ipso facto to this territory." ${ }^{147}$ The two paragraphs of Article 15 of the 1978 Convention provide for this substitution; in so doing, they ensure that, for each State, treaties are "binding in respect of its entire territory". 148

As with other rules (and as the use of the term 'generally' in Zimmermann's formulation suggests), the moving treaty frontiers rule does not apply absolutely. The law leaves room for agreement to the contrary; and where a treaty specifically relates to the ceded territory, a contrary approach may indeed be called for. Article 15 of the 1978 Vienna Convention gives effect to these considerations by admitting for exceptions to the moving frontier principle if its application "would be incompatible with the object and purpose of the treaty or would radically change the

\footnotetext{
${ }^{146}$ As the ILC noted in its commentary, instances of cession "do involve a 'succession of States' in the sense that this concept is used in the present draft articles, namely a replacement of one State by another in the responsibility for the international relations of territory" (ILC Yearbook 1974, vol. II/1, 208).

${ }^{147}$ Zimmermann, EPIL (n 17), para 8. Waldock's more complicated formulation distinguishes between a positive aspect ("the treaties of the successor State begin automatically to apply in respect of the [ceded] territory as from the date of the succession") and a negative aspect ("the treaties of the predecessor State ... cease automatically to apply in respect of the territory"); but in essence, the rule remains one of "a simple substitution of one treaty regime for another": H Waldock, Second Report on Succession in Respect of Treaties, ILC Yearbook 1969, vol. II, at 52.

${ }^{148}$ As indicated by Article 29 of the 1969 Vienna Convention on the Law of Treaties.
} 
conditions for its operation "; ${ }^{149}$ further exceptions flow from the application of Articles 11 and 12 of the 1978 Vienna Convention, pursuant to which successor States are bound to observe boundary and other localised treaties. ${ }^{150}$ But notwithstanding these exceptions, as a principle, the 'moving treaty frontiers rule' has regularly been applied, and was well established by the time of the adoption of the 1978 Vienna Convention. ${ }^{151}$

State practice since 1978 is relatively sparse. Of the few instances of cession and/or incorporation that have taken place, some would seem to affirm the approach adopted in Article 15 of the 1978 Vienna Convention, while in two particular cases, States have opted for a nuanced approach. As for confirmatory practice, the transfer of Walvis Bay from South Africa to Namibia illustrates the operation of the moving treaty frontiers rule. ${ }^{152}$ After 1994, and subject to some special arrangements, "treaties of the predecessor [South Africa] cease[d] to be in force in respect of the ceded territory while treaties of the successor [Namibia] generally extend[ed] ipso facto to [Walvis Bay]." ${ }^{153}$ By and large, the moving frontiers principle has also shaped practice during the process of German unification, generally treated as a case of incorporation, to which the rules governing cessions were applied by analogy: $:^{154}$

\footnotetext{
${ }^{149}$ Similar exceptions are included in Article 29 VCLT, pursuant to which treaties generally apply tot he entirety of a State's territory: this presumption does not apply if "a different intention appears from the treaty or is otherwise established".In the Sanum case, the arbitral tribunal held "the exceptions to Article 15 of the VCST [to be] encompassed in the exceptions to Article 29 of the VCLT" (n XX, at para. 229).

${ }^{150}$ See supra, section 4.a.

${ }^{151}$ See the references in fn. 141.

${ }^{152}$ See the Treaty between the Government of the Republic of South Africa and the Government of the Republic of Namibia with Respect to Walvis Bay and the Off-Shore Islands, International Legal Materials 33 (1994), 1526; and further Zimmermann, Staatennachfolge (n 17), 447-449. For background information see AJ Hoffmann, Walvis Bay, in Max Planck Encyclopedia of Public International Law (www.mpepil.com).

${ }^{153}$ Cf. Zimmermann, EPIL (n 17) para 8. Special arrangements were e.g. reached to accommodate the rights of South African residents in Walvis Bay and the effect of public acts rendered during the South African rule: see Hoffmann (n 152), paras. 15-17.

${ }^{154}$ See Hafner/Novak (n 17), 411-412; Zimmermann, Staatennachfolge (n 17), 245-282 (with many details). This analoguous application initially of the moving treaty frontiers rule to the unification of Germany met with some resistance, as the 1978 Vienna Convention does not lay down special rules for an incorporation of a State, but instead, in Article 31, formulated a particular rule governing the uniting of States. In the case of Germany, Article 31 clearly was not applied. For a clear analysis see Stern (n 17), 237-242.
} 
according to Article 11 of the Unification Treaty, ${ }^{155}$ agreements concluded by the Federal Republic of Germany ('FRG'), as a rule, would apply to the entire German territory; whereas the FRG would merely enter into consultations regarding the fate of the German Democratic Republic's former treaties according to Article $12 .{ }^{156}$

The two most prominent territorial transfers that have taken place since 1978 - viz. the return to China, of Hong Kong and Macao ${ }^{157}$ - however have followed a very different (perhaps indeed "unique"158) logic. As Macao and Hong Kong were to retain a special status within the PRC, the moving frontier principle was not applied in an unqualified manner. In addition to ensuring the transfer, the arrangements between China on the one hand, and the United Kingdom and Portugal on the other, sought to preserve pre-existing treaties irrespective of whether these had applied to China before the transfer. To that effect, in their bilateral Declarations of 1984 and 1987, the treaty parties did not automatically extend Chinese treaties to Hong Kong and Macao. ${ }^{159}$ More importantly, they envisaged that (as noted in the 1984 UK-China Declaration) "[i]nternational agreements to which the People's Republic of China is not a party, but which are implemented in Hong Kong, may remain implemented in the [Hong Kong Special Administrative Region]". ${ }^{160}$ As regards Hong Kong, the Joint Liaison Group established under the 1984 Declaration was to make ample use of the latter option (continued implementation) as far as multilateral treaties are

\footnotetext{
${ }^{155}$ Treaty on the Unification of Germany, International Legal Materials 30 (1991), 457.

${ }^{156}$ As Aust notes ( $\mathrm{69}, 374$ ), while not bound by the Unification Treaty, other states generally accepted the approach adopted in Articles 11 and 12. For further detail see D Papenfuß, The Fate of the International Treaties of the GDR within the Framework of German Unification, American Journal of International Law 92 (1998) 469; and the references in fn. 154.

${ }^{157}$ Whether these instances are properly characterised as 'State succession' is a matter of controversy: according to the PRC's view, it was a mere "resumption" of sovereignty over territories that had never been ceded. However, even on that basis, both instances would involve the "the replacement of one State by another in the responsibility for the international relations of territory" (as per Article 2(1)(b) of the 1978 Vienna Convention). For comment see the Sanum award, at para. 237; but cf. Wang (n 13), 569-570.

${ }^{158}$ Aust (n 69), 386.

${ }^{159}$ See International Legal Materials 1984, 1366 (Joint UK-China Declaration) and UN Treaty Series, vol. 1498, 228 (Joint China-Portugal Declaration). For a fuller analysis see R Mushkat, Hong Kong and Succession of Treaties, International and Comparative Law Quarterly 46 (1997), 181; Zimmermann, Staatennachfolge (n 17), 432-337; and Cheng (n 15), 209-236.

${ }^{160}$ See Annex I, Section XI of the 1984 Joint UK-China Declaration (n 159).
} 
concerned; with the result that, "with few exceptions, multilateral treaties which had applied to Hong Kong before handover continued to apply thereafter in all essential respects" ${ }^{161}$ For bilateral treaties, the parties were also keen to preserve some autonomy for Macao and Hong Kong, but adopted a different approach: in the words of one commentator (speaking to the situation in Hong Kong), "none of the then existing bilateral treaties with third States would apply to the HKSAR after handover." ${ }^{162}$ Rather, Hong Kong and Macao were entrusted directly to conclude bilateral agreements in their own right, which would then remain in force.

These considerations highlight the flexibility of the general framework, which does not preclude States from agreeing on special solutions for particular problems - and which in the case of Hong Kong and Macao, allowed the parties to implement the 'one country, two systems' approach that informed the eventual arrangements. Looking at developments since 1978, perhaps it could be said that practice has not only been sparse, but also dominated by unusual cases; and that the arrangements reached with respect to Hong Kong and Macao (and to some extent Germany) reflect that fact.

b) Investment Treaty Practice: Agreement on Principle, but Difficulties with 'Unique' Cases

Investment treaty practice largely mirrors the general developments outlined in the preceding section. Given the recent focus on the Sanum litigation with its contradictory outcomes, it is worth underlining that there is a large measure of agreement on the applicable regime, and on the presumptive relevance of the moving frontiers principle in particular.

Read properly, the decisions rendered in the Sanum litigation reflect different interpretations of the peculiar status of Macao under Chinese BITs entered into before Macao's return. These different interpretations might have implications for

\footnotetext{
${ }^{161}$ Aust (n 69), 390.

${ }^{162}$ Aust (n 69), 390.
} 
the status of Hong Kong (in relation to which similar questions might arise), but are unlikely to be of more general relevance. In fact, in their approach to the status of Macao, the UNCITRAL arbitral tribunal and the Singapore High Court may not have been that far apart. Proceeding from the rule set out in Article 15 of the 1978 Vienna Convention, they both agreed that treaties presumptively applied to the entirety of a State's territory (and thus 'moved' with the treaty party's frontiers), but that this presumption could be rebutted. The main question dividing them was whether the applicable BIT between China and Laos came within the scope of the exceptions to the principle. Their disagreement on this point can however to some extent be explained by the availability of evidence: while the arbitral tribunal had to decide in the absence of instructive information, ${ }^{163}$ the Singapore High Court could rely on an exchange of letters, between China and Laos, suggesting that the BIT should not apply to Macao. ${ }^{164}$ This party agreement (once accepted and admitted into the proceedings ${ }^{165}$ ) clearly strengthened the case for an exception. Conversely, the reliance placed on it limits the impact of the Sanum decision on future cases; the status of Macao (and Hong Kong) in relation to other Chinese BITs notably remains open to debate. ${ }^{166}$ Unless the parties to these treaties follow the lead of China and Laos and provide explicit clarification, ${ }^{167}$ the matter is likely to be argued in future disputes implicating Hong Kong or Macao (or Hong Kong/Macao-based claimants): on the basis of the considerations advanced above, ${ }^{168}$ the better view would be to accept that for the unusual cases of cessions such as Hong Kong and Macao (which

\footnotetext{
${ }^{163}$ See para. 232 of the Sanum UNCITRAL award (n 9), referring to the "paucity of factual elements presented by the Parties".

${ }^{164}$ According to the Singapore High Court, this was a "key plank" of the evidence: see Singapore High Court (n 10), para. 38.

${ }^{165}$ Whether the letters should be admitted at the review stage (even though they were produced after the arbitral tribunal had rendered its award) was a crucial question: see paras. 43-56 of the High Court judgment (n 10); and Hwang/Chang (n 13), 517-519, for comment.

${ }^{166}$ See Hart/Srikumar (n 13), 198: "the letters exchanged in relation to the China-Laos BIT will have little salience for the interpretation of other BITs in future disputes."

${ }^{167}$ It is worth noting that some of China's BITs expressly address the matter: see e.g. the 2006 ChinaRussia BIT and Protocol (stipulating that "[u]nless otherwise agreed by both Contracting Parties, the Agreement does not apply to the Hong Kong Special Administrative Region of the People's Republic of China and the Macao SpecialAdministrative Region of People's Republic of China").

${ }^{168}$ See above, section 5.a.
} 
purposefully avoid the full integration of the ceded territory), the moving treaty frontiers rule needs to be qualified. ${ }^{169}$

Whatever position is taken on the geographical scope of Chinese BITs, it is worth noting that outside the particular arrangements obtaining in Macao and Hong Kong, cessions and incorporations raise few problems. The limited practice available so far in fact suggests that they are dealt with routinely, by a simple application of the moving frontiers rule. In line with that rule, German BITs concluded before unification were routinely applied to the GDR after $1990 .{ }^{170}$ As for institutional arrangements, Germany's ICSID membership was automatically extended to cover the united Germany in its entirety. ${ }^{171}$ As regards Walvis Bay, the available evidence is limited; however, it seems the one investment treaty concluded by South Africa prior to 1994 (a 1974 BIT with Portugal) did not apply to Walvis Bay after its return to Namibia. ${ }^{172}$ Lastly, it is worth noting that, at least in respect of the ICSID Convention, the arbitral tribunal in Tza Yap Shum v. Peru applied the moving treaty frontiers principle even in relation to China/Hong Kong: assessing the propriety of a claim by a Hong Kong-based investor, the tribunal was content to note that China had not excluded the application of the ICSID Convention to Hong Kong pursuant to its Article 70; under those circumstances, it was sufficient for the investor to establish that it was a Chinese national (irrespective of the place of its

\footnotetext{
${ }^{169}$ As a separate matter, it is worth considering whether, in relation to Macao- (or Hong Kong-)based claimants invoking provisions of Chinese BITs, the place of incorporation is determinative: according to Hart/Srikumar, "whether the Macanese company enjoyed the BIT's protection should have turned on the company's nationality", not the place of its incorporation: see Hart/Srikumar (n 13), 195-197. On the respective roles of nationality and geographical scope of application see further the award in Tza Yap Shum $v$ Republic of Peru (Decision on Jurisdiction and Competence) (ICSID Case No ARB/07/06), at paras. 67-77, and below, text at fn. 173.

${ }^{170}$ This followed from Article 11 of the Unification Treaty (n 155). The German government notified its treaty partners of the approach adopted under that treaty; its diplomatic notes met with little, if any, resistance: see Zimmermann, Staatennachfolge (n 17), 246-251 with references.

${ }^{171}$ Given the distinct legal regimes addressed in sections 3 and 4 above, it bears underlying that the moving treaty frontiers rule covers institutional treaties as well. In line with this, Article 11 of the Unification Treaty ( $n$ 155) expressly mentioned treaties involving membership in international organisations.

${ }^{172}$ For brief information see L Poulsen, Bounded Rationality and Economic Diplomacy (2015), 168 (fn. 28).
} 
incorporation). ${ }^{173}$ All this suggests that instances of cession and incorporation do not give rise to any conceptual problems.

\section{Concluding Observations}

The preceding sections have revisited some of the more relevant issues facing investment lawyers as they seek to apply rules of State succession to investment treaty law. Notwithstanding the popular perception of State succession as a hotbed of legal controversy, it is worth noting that there are relevant areas of agreement, where the law is settled. The treatment of membership rights (not generally susceptible to be 'inherited' by succession) is one such area; the impact of the moving treaty frontiers principle on cessions of territory (resulting, under normal circumstances, in the extension of treaties of the 'receiving State') another. When these issues have arisen, arbitral investment treaty practice seems to follow the general regime: hence new States join ICSID as new members, and debates about cessions of territory proceed from the moving treaty frontiers principle, which provides the widely-agreed starting point and applies presumptively.

Needless to say that not everything is settled; the preceding sections have also highlighted areas of contestation and uncertainty. The proper application of the moving treaty frontiers principle to unusual cessions of territory - such as those involving Macao and Hong Kong - counts among these. Notwithstanding two decisions by an UNCITRAL arbitral tribunal and the Singapore High Court, the status of the two territories with respect to Chinese BITs so far remains uncertain: as noted above, the better view would be to treat Macao and Hong Kong as special instances of cession not presumptively governed by the moving treaty frontier principle.

While raising important legal issues, the status of Macao and Hong Kong under Chinese BITs is a specific problem that implicates relatively marginal aspects of the regime of succession. By contrast, the status of new States in relation to BITs

\footnotetext{
${ }^{173}$ Tza Yap Shum v. Peru (n 169), at paras. 68-70. Whether the same argument should apply to a BIT is a matter of debate: see supra, fn. 169.
} 
concluded by their predecessors raises structural questions of general relevance: this is a major area of uncertainty. As the above analysis demonstrates, investment tribunals have so far avoided a full engagement with the long-standing conceptual debate between 'strict continuity' and 'clean slate' approaches. To some extent, they could do so as (in line with general developments), State parties to investment treaties have frequently determined the fate of prior BITs through explicit agreements - which almost inevitably ensure continuity in investment treaty relations. Given the renewed popularity, in recent scholarship, of the long-standing conceptual debate, it is worth underlining that, where no explicit agreement has been reached, there is room to engage with arguments based on implied, or tacit, consent: such arguments no doubt need to be made carefully, but in principle are available. The key task throughout is to identify the intention of the (putative) parties to the treaty, which does not have to be expressed in a particular form. Only if neither explicit nor implied consent can be established does the question of automatic succession to BITs arise. As noted above, the argument in favour of automaticity is a difficult one, as bilateral treaties have traditionally been seen as mere inter-State exchanges of benefits. However, claims for automatic treaty continuity should not be dismissed out of hand. They can e.g. be supported by reference to the particular nature of BITs, which after all establish rights of thirdparty beneficiaries; these could be said to devolve with the territory.

Stepping back from the debates about particularities, it is interesting to note that so far, the application of State succession rules to investment treaties has so far rarely become a major issue (though cases such as Sanum and World Wide Minerals may signal a change). To the extent that it is settled, investment lawyers seem comfortable in applying the general regime of State succession: by and large, they accept the general rules and give effect to them within the field of investment law. Where the general regime is uncertain (as it notably is with respect to new States and prior BITs), investment tribunals have sought to 'muddle through' in search for pragmatic and equitable solutions; they have (to adapt Lord Wright's description) "proceed[ed] from case to case, like the ancient Mediterranean mariners, hugging the coast from point to point and avoiding the dangers of the open sea of system 
and science". ${ }^{174}$ Such an approach is understandable, as the general regime of State succession can indeed very much feel like an 'open sea' and - unlike other core aspects of public international law - needs to be approached without the benefit of detailed charts and compasses. But conversely, having 'hugged the coast', investment tribunals have so far done relatively little to clarify the law of State succession: they have tended to be receivers of general rules, not shaped them. This in turn has meant that an area of law rather in need of clarification remains in many ways obscure: the potential of arbitral awards to consolidate and develop the law has so far not been realised.

A final thought: if the application of State succession rules has so far rarely become a major issue in investment arbitration, this would also seem to suggest that investment treaties are not viewed as particular controversial commitments. As noted above, in many instances, successor States are quite happy to continue them. This preference for stability in investment treaty relations is in line with general trends in recent succession practice - and yet, it deserves to be mentioned, as it stands in marked contrast to debates during decolonisation, when arrangements benefiting foreign investors (then typically contract-based) prompted major controversy. Seen in this light, the pragmatic handling of State succession issues may be taken to reflect a gradual acceptance of the investment protection regime over the past decades.

${ }^{174}$ See RA (Lord) Wright, The Study of the Law, Law Quarterly Review 54 (1938), 185, at 186. 